OPEN ACCESS

Edited by:

Vanessa Pinho,

Federal University of Minas

Gerais, Brazil

Reviewed by:

Maryna Skok

Palladin Institute of Biochemistry (NAS

Ukraine), Ukraine

Marina Castor,

Federal University of Minas

Gerais, Brazil

*Correspondence:

Eva M. J. Peters

eva.peters@eva-peters.com

${ }^{\dagger}$ These authors have contributed equally to this work

Specialty section

This article was submitted to

Inflammation,

a section of the journal

Frontiers in Immunology

Received: 21 November 2020

Accepted: 24 February 2021

Published: 18 March 2021

Citation:

Ertle CM, Rommel FR, Tumala S, Moriwaki Y, Klein J, Kruse J, Gieler U and Peters EMJ (2021) New Pathways for the Skin's Stress Response: The Cholinergic Neuropeptide SLURP-1

Can Activate Mast Cells and Alter Cytokine Production in Mice.

Front. Immunol. 12:631881.

doi: 10.3389/fimmu.2021.631881

\section{New Pathways for the Skin's Stress Response: The Cholinergic Neuropeptide SLURP-1 Can Activate Mast Cells and Alter Cytokine Production in Mice}

Christoph M. Ertle ${ }^{1 \dagger}$, Frank R. Rommel ${ }^{1 \dagger}$, Susanne Tumala ${ }^{1}$, Yasuhiro Moriwaki ${ }^{2}$, Jochen Klein ${ }^{3}$, Johannes Kruse ${ }^{4,5}$, Uwe Gieler ${ }^{6}$ and Eva M. J. Peters ${ }^{1,7 *}$

${ }^{1}$ Psychoneuroimmunology Laboratory, Clinic for Psychosomatic Medicine and Psychotherapy, Justus-Liebig-University Giessen, Giessen, Germany, ${ }^{2}$ Department of Pharmacology, Keio University Faculty of Pharmacy, Tokyo, Japan, ${ }^{3}$ Department of Pharmacology, Biocenter N260, Goethe University Frankfurt, Frankfurt, Germany, ${ }^{4}$ Clinic for Psychosomatic Medicine and Psychotherapy, Justus-Liebig-University Giessen, Giessen, Germany, ${ }^{5}$ Clinic for Psychosomatic Medicine and Psychotherapy, Philipps University of Marburg, Marburg, Germany, ${ }^{6}$ Department of Dermatology, University Hospital Giessen, Giessen, Germany, ${ }^{7}$ Charité Center 12 for Internal Medicine and Dermatology, Charité - Universitätsmedizin Berlin, Berlin, Germany

Background: The alpha7 nicotinic acetylcholine receptor (Chrna7) plays an essential anti-inflammatory role in immune homeostasis and was recently found on mast cells (MC). Psychosocial stress can trigger MC hyperactivation and increases pro-inflammatory cytokines in target tissues such as the skin. If the cholinergic system (CS) and Chrna7 ligands play a role in these cascades is largely unknown.

Objective: To elucidate the role of the CS in the response to psychosocial stress using a mouse-model for stress-triggered cutaneous inflammatory circuits.

Methods: Key CS markers (ACh, Ch, SLURP-1, SLURP-2, Lynx1, Chrm3, Chrna7, Chrna9, ChAT, VAChT, Oct3, AChE, and BChE) in skin and its MC (sMC), MC activation, immune parameters (TNF $\alpha, I L 1 \beta, I L 10, T G F \beta, H I F 1 \alpha$, and STAT3) and oxidative stress were analyzed in skin from $24 \mathrm{~h}$ noise-stressed mice and in cultured MC (cMC) from C57BL/6 or Chrna7-Knockout mice.

Results: First, Chrna7 and SLURP-1 mRNA were exclusively upregulated in stressed skin. Second, histomorphometry located Chrna7 and SLURP-1 in nerves and sMC and demonstrated upregulated contacts and increased Chrna7 + sMC in stressed skin, while $5 \mathrm{ng} / \mathrm{mL}$ SLURP-1 degranulated $\mathbf{c M C}$. Third, IL $1 \beta+\mathbf{s M C}$ were high in stressed skin, and while SLURP-1 alone had no significant effect on cMC cytokines, it upregulated IL $1 \beta$ in cMC from Chrna7-KO and in IL1 $\beta$-treated wildtype cMC. In addition, HIF1 $\alpha+$ sMC were high in stressed skin and Chrna7-agonist AR-R 17779 induced ROS in cMC while SLURP-1 upregulated TNF $\alpha$ and IL1 $\beta$ in cMC when HIF1 $\alpha$ was blocked. 
Conclusions: These data infer that the CS plays a role in the regulation of stress-sensitive inflammatory responses but may have a surprising pro-inflammatory effect in healthy skin, driving IL1 $\beta$ expression if SLURP-1 is involved.

Keywords: Chrna7 knockout, mast cells, alpha7 nicotinic acetylcholine receptor, cholinergic system, secreted Ly-6/uPAR-related protein 1, hypoxia inducible factor 1 alpha, stress

\section{INTRODUCTION}

The present concept of how peripheral organs engage in a systemic stress response, describes the upregulation of neuronal and non-neuronal neuroendocrine factors in peripheral tissues as a consequence of perceived stress. Along this so called brain-body-axis, neuroendocrine mediators such as cortisol (nor)adrenaline, substance P (SP), or nerve growth factor (NGF) are generated by the activation of systemic stress response systems such as the hypothalamus-pituitary-adrenal axis (HPA), the sympathetic axis (SA) and the sensory nervous system (SNS). They are then transported into the peripheral organs via blood vessels or reach them via peripheral autonomic and sensory nerve fibers (1). Organs at the self-environment interface such as the skin, lung or gut are densely innervated and have a rich blood supply, which enables a close neuroimmune interaction in these organs in response to systemic stressors. In parallel and interacting with this systemic stress response, there exist neuroendocrine systems of the peripheral organs themselves. Epithelial cells and immunocytes for example produce and secrete neuroendocrine stress mediators locally and communicate via auto- and para-mechanisms with the systemic stress response systems (2-8). In the stress response, this close interaction serves the maintenance of homeostasis but can become psychotoxic if exaggerated $(9,10)$.

The CS is a highly preserved neuroendocrine signaling system that contributes to allostasis of both non-neuronal and neuronal cells (11-14). Acetylcholine is produced and released by various epithelial and immune cells in response to stress $(7,15,16)$, including innate immunocytes such as mast cells (MC), which line organs bordering the environment and which can become activated by stress and its mediators $(17,18)$. This suggests that this neurotransmitter may also play a role in brain-body

Abbreviations: Ach, Acetylcholine; AChE, acetylcholinesterase; AID, atopiclike dermatitis allergic dermatitis; $\mathrm{BChE}$, butyrylcholinesterase; $\mathrm{Ch}$, choline; ChAT, choline acetyltransferase; Chrm3, muscarinic acetylcholine receptor 3; Chrna7, alpha nicotinic acetylcholine receptor 7; Chrna7-KO, alpha nicotinic acetylcholine receptor 7 knockout; Chrna9, alpha nicotinic acetylcholine receptor 9; cMC, cultured mast cells; CS, cholinergic system; DCFH-DA, dichlorofluorescein diacetate; DNP-HAS, dinitrophenyl albumin; HAD, $\beta$ hexosaminidase degranulation assay; HM, histomorphometry; HIF1 $\alpha$, hypoxia inducible factor 1 alpha; HPLC, high-performance liquid chromatography; IHC, immunohistochemistry; IL10, interleukin 10; IL1 $\beta$, interleukin 1 beta; Lynx1, Ly6/Neurotoxin 1; MC, mast cells; NGF, Nerve Growth Factor; Oct3, organic cation transporter 3; PMA, Phorbol 12-myristate 13-acetate; ROS, reactive oxygen species; SLURP-1, secreted Ly-6/uPAR-related protein 1; SLURP-2, secreted Ly6/uPAR-related protein 2; sMC, skin mast cells; SP, substance P; STAT3, signal transducer and activator of transcription 3; TBP, TATA box binding protein; TGF $\beta$, transforming growth factor beta; $\mathrm{TNF} \alpha$, tumor necrosis factor alpha; VAChT, vesicular acetylcholine transporter; WT, wildtype. interaction. Moreover, ChAT + nerve fibers can be found to make close contacts with immunocytes in epithelial tissues, which suggests that both the neuronal and non-neuronal cholinergic systems (CS) participate in the CS stress response (11-14).

Recently, psychosocial stress was shown to result in a prominently altered expression of the alpha7 nicotinic acetylcholine receptor (Chrna7) together with an altered expression of a peptidergic modulator of Chrna7 activity, the Secreted Ly-6/uPAR-related protein 1 (SLURP-1) (7).

Chrna7 is known for its impressive capacity to attenuate toxic hyper-inflammatory responses to a wide variety of stressors and it is reduced in chronic inflammatory skin diseases (19-21). This drew our attention to SLURP-1 as a potential controller of proinflammatory responses to stress (22). To our surprise, a screen of the respective literature revealed that the precise role of the CS in the response to psychosocial stress is largely unknown and even less is known about a role for SLURP-1. Some information was even contradictory, suggestive of both, a protective and a harmful role of the CS in host defense and inflammatory disease $(12,16,23-25)$. This called for research that clarifies the role of SLURP-1 at the crossroads between pro-inflammatory and anti-inflammatory stress responses.

Since prominent SLURP-1 expression was found in the skin, we decided to focus on the skin as a target organ to study SLURP1 in stress. Placed at the border between self and environment, the skin acts as the first line of defense against environmental challenges and protects the organism from harm (26-30). Innate immune cells such as MC stand in this first line to serve their duty by locally sensing and responding to tissue insults such as bacteria or tumor cells. They do this in close interaction with the skin's innervation that links the skin's stress response to systemic stress cascades that prepare the organism for flight or fight and promote an adaptive response to the stress (31-35). When skin MC are hyperactivated by psychotoxic stress however, they can initiate and worsen inflammation to an extent that makes it maladaptive and promotes allergic inflammation or initiates tissue damage even in otherwise healthy skin (36-41). We had previously shown this in studies focusing on the sensory neuropeptide SP as a key mediator of psychotoxic stress in skin and driver of deleterious inflammation $(4,6,41,42)$.

As SLURP-1 is widely considered to be an allosteric agonist of the Chrna7 expressed by primary sensory neurons, epithelial cells and selected cells of the immune system (43-46), we expected SLURP-1 to have an attenuating effect on these pro-inflammatory cascades. To fill this knowledge gap, we analyzed the skin of mice stressed by noise-exposure and MC from wildtype (WT) and Chrna7-Knockout (Chrna7-KO) mice to answer the following questions: (1) Are SLURP-1 and Chrna7 together with other CS 
components regulated in the skin by stress and, thus, who are the relevant players in the healthy skin's stress response? (2) What are the neuronal and non-neuronal cellular targets of thus identified stress-sensitive players of the skin's CS? And (3) Does the CS modulate the skin's cytokine-balance of pro- and antiinflammatory stress responses? The answers to these questions will be highly valuable for the future tailoring of CS interventions designed to treat maladaptive inflammatory stress responses.

\section{MATERIALS AND METHODS}

\section{Animals}

Twenty female 7-8 weeks old C57BL/6 mice (Charles River, Sulzfeld, Germany) were randomly sorted into two groups (control, stress) on arrival at the animal facility at Universitätsmedizin-Charité, Berlin, Germany as described previously (36). Animal care and experimental procedures of the stress experiments were approved by the institutional review board and conformed to the requirements of the state authority for animal research (LaGetSi, Berlin, Germany) and complied with the ARRIVE guidelines and were carried out in accordance with the EU Directive 2010/63/EU for animal experiments. Additionally, whole thickness skin biopsies with a diameter of $3 \mathrm{~mm}$ and both bone marrow-derived and peritoneal MC were obtained for culture (cMC) from 20 to 24 weeks old WT and Chrna7-KO mice as described previously $(47,48)$. The corresponding background strain (C57BL/6J) was used as WT control mice with permission of the state of Hesse, Regierungspräsidium Giessen, according to section 8 of the German Law for the Protection of Animals and conform with the NIH guide for the care and use of laboratory animals. Generation and characterization of these Chrna7-KO animals are described elsewhere (49). All mice were housed under a 12-h-light: 12-h-dark cycle in temperature-regulated rooms $\left(22-24^{\circ} \mathrm{C}\right)$, under ambient humidity, with food and water ad libitum until experiments were performed. All animals used in this study were genotyped as described by Moser et al. (50). Approximately $0.5 \mu \mathrm{g}$ DNA was used for qPCR using the Kapa mouse genotyping Kit (Peqlab, Erlangen, Germany) according to published protocols (51).

\section{Noise-Stress Mouse Model}

As previously described, mice within the stress group were exposed to noise $(300 \mathrm{~Hz}$ tone, emitted at irregular intervals four times per minute; rodent repellent device, Conrad Electronics, Hirschau, Germany) for a single $24 \mathrm{~h}$ period $(4,52)$. Noise is long known to cause a systemic stress response and at the same time alter local skin homeostasis in humans and mice $(53,54)$. It is therefore frequently used as an experimental stress paradigm to study biomolecular stress responses to psychosocial stress on the organ level.

\section{Skin Harvesting}

Tissue samples from mice stressed as described above as well as unstressed control mice were collected, snap-frozen in liquid nitrogen and stored at $-80^{\circ} \mathrm{C}, 48 \mathrm{~h}$ after termination of the stress exposure to be used for microarray, high-performance liquid chromatography (HPLC), qPCR and immunohistochemistry (IHC) protocols as described below and published previously $(51,55,56)$.

\section{HPLC}

The mouse back skin biopsies of atopic-like dermatitis (AlD)stress-model were powdered in liquid nitrogen using a ball mill. Around $15 \mathrm{mg}$ of the powder were dissolved in $500 \mu \mathrm{l}$ of homogenization buffer $(150 \mu \mathrm{l} 1 \mathrm{~N}$ acetic acid $99 \%+850$ $\mu \mathrm{l}$ acetone) for the use in HPLC analysis. Choline $(\mathrm{Ch})$ and Acetylcholine (ACh) measurement was performed by HPLC protocols as previously published (57).

\section{qPCR}

As described above, the mouse back skin biopsies were powdered and $\sim 50 \mathrm{mg}$ biopsy powder was used for RNA isolation followed by qPCR of skin biopsies done according to the protocols of our previous study (51). For RNA isolation from peritoneal lavage derived cMC, cell lysates were directly dissolved in RLT buffer, without the ball mill step, and continued as described above. Thirty-two microlitre, containing $4 \mu \mathrm{g}$ of isolated RNA, were then transcripted into cDNA which was used for qPCR. Specific forward, reverse primers and Taqman probes (TIB MOLBIOL, Berlin, GER) used in this study are described in Table 1. Hypoxanthine Guanine Phosphoribosyltransferase (HPRT) and TATA box binding protein (TBP) were validated as reference genes for qPCR analyses. TBP levels showed best results and were constant between treatment groups as reported by others (58). Therefore, gene expressions were normalized to the internal control TBP using a modified version of $\Delta \Delta C T$ method (59). The means of control animal samples were set to 1 .

\section{IHC}

IHC was performed with $14 \mu \mathrm{m}$ thick mouse back-skin cryostat sections as described previously (51). The primary antibodies used in this study are given in Table 2. Standard controls were performed by omission of the primary antibodies and by incubation with mouse IgG1 instead of primary antibodies. Of the two different antibodies tested for SLURP-1, only the established antibody from Moriwaki et al. gave positive staining (44). No labeling was observed in negative controls of Chrna7 staining as published previously (51). Besides, the Chrna7 antibody was tested on $\mathrm{KO}$ tissue and no staining was observed (not shown). Five percentage normal serum (Dianova, Hamburg, Germany) of the species in which the secondary antibody was generated was used as blocking solution. 0.3\% Triton X-100 (Sigma-Aldrich, München, Germany) was added to the primary antibodies as detergent. Cell nuclei were counterstained with DAPI (4',6-Diamidin-2-phenylindol), skin MC (sMC) with Fluorescein Avidin D (FITC-Avidin) as described previously $(6,68)$. ProLong ${ }^{\circledR}$ Gold (Life Technologies, Darmstadt, Deutschland) was used as mounting medium. At least 10 microscopic fields and two sections per animal and antibody were analyzed with a fluorescence microscope (DMI 6000B, Leica, Wetzlar, Germany) and histomorphometry (HM) was performed as described previously (56). 
TABLE 1 | List of primers and Taqman probes used for QPCR.

\begin{tabular}{|c|c|}
\hline Genes & Primer and probe sequences \\
\hline AChE & $\begin{array}{l}\text { Forward: CCTGAACCTGAAGCCCTTAGA } \\
\text { Reverse: CAGAGTATCGGTGGCGCTG } \\
\text { Taqman probe: 6FAM-AAAGCGATTCCAGAAGGCGCA- -BBQ }\end{array}$ \\
\hline $\mathrm{BChE}$ & $\begin{array}{l}\text { Forward: GCTTACCTCTGGGAAGAAGAGTTAA } \\
\text { Reverse: TCAGTACTTGTGAAGACAGGCCAC } \\
\text { Taqman probe: } \\
\text { 6FAM-AGTCGATCCATAATGAAAACTTGGGCAAA- -BBQ }\end{array}$ \\
\hline ChAT & $\begin{array}{l}\text { Forward: CCAggACggTCCTCTTAAAAgAC } \\
\text { Reverse: CCCTgTgTgTgTCACTgAggT } \\
\text { Taqman probe: 6FAM-CgggACTCCCTggACATgATCgAgC- -BBQ }\end{array}$ \\
\hline Chrm3 & $\begin{array}{l}\text { Forward: GAGTGAACCATATCCTTCCCATCA } \\
\text { Reverse: CTTGGTCACTTGGTCAGAACG } \\
\text { Taqman probe: } \\
\text { 6FAM-CACCACAGAGACTCTCCTCTTGAAGTGCT- -BBQ }\end{array}$ \\
\hline $\begin{array}{l}\text { Chrna7 } \\
\text { Exon 1-4 }\end{array}$ & $\begin{array}{l}\text { Forward: CCTGCAAGGCGAGTTCC } \\
\text { Reverse: CTCAGGGAGAAGTACACGGTGA } \\
\text { Taqman probe: 6FAM-CTGGTCAAGAACTACAACCCGCTGGA- } \\
\text {-BBQ }\end{array}$ \\
\hline $\begin{array}{l}\text { Chrna7 } \\
\text { Exon 5-7 }\end{array}$ & $\begin{array}{l}\text { Forward: AACGTCTTGGTGAATGCATCTG } \\
\text { Reverse: CACCCTCCATAGGACCAGGAC } \\
\text { Taqman probe: 6FAM-CATTGCCAGTATCTCCCTCCAGGCA- } \\
\text {-BBQ }\end{array}$ \\
\hline $\begin{array}{l}\text { Chrna7 } \\
\text { Exon 8-10 }\end{array}$ & $\begin{array}{l}\text { Forward: GCCCTTGATAGCACAGTACTTCG } \\
\text { Reverse: GATCCTGGTCCACTTAGGCATTा } \\
\text { Taqman probe: 6FAM-CAGTGGTCGTGACAGTGATTGTGCTGC- } \\
\text {-BBQ }\end{array}$ \\
\hline Chrna9 & $\begin{array}{l}\text { Forward: TACAACAAGGCCGATGACGAG } \\
\text { Reverse: TGGTGAGTCCCAGGTGATGAG } \\
\text { Taqman probe: 6FAM-CCAACGTGGTCCTGCGGTACGAT- -BBQ }\end{array}$ \\
\hline $\mathrm{HIF} 1 \alpha$ & $\begin{array}{l}\text { Forward: GGGCCATATTCATGTCTATGATACC } \\
\text { Reverse: GGCTCATAACCCATCAACTCAGTAAT } \\
\text { Taqman probe: 6FAM-ACGGATGAGGAATGGGTTCACAAATC- } \\
\text {-BBQ }\end{array}$ \\
\hline IL10 & $\begin{array}{l}\text { Forward: gACTTCTTCAAACAAAggACC } \\
\text { Reverse: gCTTggCAACCCAAgTAA } \\
\text { Taqman probe: 6FAM-ACTgCTAACCgACTCCTTAATgCAgg- } \\
\text {-BBQ }\end{array}$ \\
\hline $\operatorname{IL} 1 \beta$ & $\begin{array}{l}\text { Forward: AAAgAATCTATACCTgTCCTgTgT } \\
\text { Reverse: gCTIggATCCACACTCTCC } \\
\text { Taqman probe: 6FAM-AAgACggCACACCCACCCTgCAgCT- } \\
\text {-BBQ }\end{array}$ \\
\hline Lynx1 & $\begin{array}{l}\text { Forward: CCTGTGGCCCAGGCTCT } \\
\text { Reverse: GGTGAAGTAAGTTCGTGTGGTCATAC } \\
\text { Taqman probe: } \\
\text { 6FAM-TGTGCCTACAATGGAGACAACTGCTTCAA- -BBQ }\end{array}$ \\
\hline Oct3 & $\begin{array}{l}\text { Forward: CTGGCTGATCACCCGGA } \\
\text { Reverse: AACAGGATGGGTTACTGACTTCTTCA } \\
\text { Taqman probe: 6FAM-AGGTGTITCCATTGCACTTAGCCACGC- } \\
\text {-BBQ }\end{array}$ \\
\hline SLURP-1 & $\begin{array}{l}\text { Forward: gAgCATgggCTATggTgAgg } \\
\text { Reverse: TTgAAggggAACgCTgCTT } \\
\text { Taqman probe: 6FAM-TgCAAgATggAAgACACAgCCTgTAAgAC- } \\
\text {-BBQ }\end{array}$ \\
\hline SLURP-2 & $\begin{array}{l}\text { Forward: TCATCATTGCCACCCGTTCT } \\
\text { Reverse: CCAAGCTGGAGACATCAGGAC } \\
\text { Taqman probe: 6FAM-TAGCACATCTTCGTCACCAGAGGCAGA- } \\
\text {-BBQ }\end{array}$ \\
\hline STAT3 & Forward: GCTGGTCAAATTTCCTGAGTTGAA \\
\hline
\end{tabular}

(Continued)
TABLE 1 | Continued

\begin{tabular}{|c|c|}
\hline Genes & Primer and probe sequences \\
\hline & $\begin{array}{l}\text { Reverse: AGAATGTTAAATTCCGAGACCCTC } \\
\text { Taqman probe: } \\
\text { 6FAM-AGCAACATCCCCAGAGTCTTTATCAATGCA- -BBQ }\end{array}$ \\
\hline ТВP & $\begin{array}{l}\text { Forward: gTgAATCTTggCTgTAAACTTgACCT } \\
\text { Reverse: gCAgTTgTCCgTggCTC } \\
\text { Taqman probe: 6FAM-AAATgCTgAATATAATCCCAAgCgATTTgC- } \\
\text {-BBQ }\end{array}$ \\
\hline TGF $\beta 2$ & $\begin{array}{l}\text { Forward: GCAAAACCCCAAAGCCAG } \\
\text { Reverse: GTGGGAGATGTTAAGTCTITGGA } \\
\text { Taqman probe: 6FAM-TCAATCCGCTGCTCGGCCA- -BBQ }\end{array}$ \\
\hline $\mathrm{TNF} \alpha$ & $\begin{array}{l}\text { Forward: gCCTATgTCTCAgCCTCTTCTCATT } \\
\text { Reverse: CCACTTggTggTTIgCTACgA } \\
\text { Taqman probe: 6FAM-CCATAgAACTgATgAgAgggAggCCATाT- } \\
\text {-BBQ }\end{array}$ \\
\hline VAChT & $\begin{array}{l}\text { Forward: CCCTTAAgCgggCCTTC } \\
\text { Reverse: CgAAgAgCgTggCATAgTCT } \\
\text { Taqman probe: 6FAM-TIgATCgCATgAgCTACgACgTgC- -BBQ }\end{array}$ \\
\hline $\begin{array}{l}\text { AChE, } \\
\text { cholineace } \\
\text { alpha nico } \\
\text { Ly6/neuro }\end{array}$ & 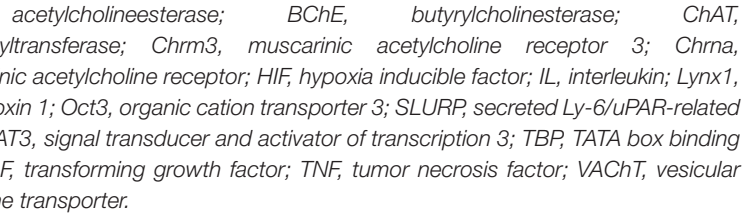 \\
\hline
\end{tabular}

\section{Generation of MC Cultures}

Since MC are highly fragile cells and do not survive cell sorting protocols with high cell yields and are generally not amenable to culture after sorting due to poor viability and susceptibility to contamination, we employed the following harvesting, enrichment and amplification method to obtain MC for cell culture experiments: (1) cMC from bone marrow. This method yields more immature $\mathrm{cMC}$ that can be cultured over longer periods of time. (2) cMC from peritoneal lavage. This method yields more mature cMC. In order to generate $\mathrm{MC}$ cultures, standard operating procedures employing growth-factor induction of $\mathrm{cMC}$ differentiation were followed as published elsewhere (69) with minor modifications as described below.

\section{Bone Marrow-Derived cMC}

Mice were deeply anesthetized with $20 \mu \mathrm{l}$ per gram body weight of a Ketamin $(25 \mathrm{mg} / \mathrm{ml})$ and Xylazin $(2 \%)$ mixture and killed by cervical dislocation. After cleaning the legs with $70 \%$ ethanol and removing them, femur and tibia were exposed from surrounding tissue. Using a sterile syringe, the bones were rinsed with $3 \mathrm{ml}$ of preheated $\mathrm{cMC}$ medium. The bone marrow was collected and centrifuged at $1,200 \mathrm{rpm}$ for $3 \mathrm{~min}$ at room temperature. The supernatant was removed, cells were resuspended in fetal calf serum [FCS] and 10\% DMSO and stored in $-80^{\circ} \mathrm{C}$. Prior to experiments, cells were defrosted, washed and resuspended with cMC medium (RPMI medium containing: $10 \%$ FCS, 1 M HEPES, $1 \%$ non-essential amino acids, $1 \%$ penicillinstreptomycin [Pen/strep], $1 \%$ glutamine, $1 \%$ sodium pyruvate, 
TABLE 2 | List of primary and secondary antibodies used for immunofluorescence.

\begin{tabular}{|c|c|c|c|}
\hline Target & Source & Dilution & Type/Reference \\
\hline Rabbit polyclonal anti TNF $\alpha$ & Abcam (Cambridge, UK) & $1: 200$ & ab34674 (60) \\
\hline Rabbit polyclonal anti IL1 $\beta$ & Abcam (Cambridge, UK) & $1: 100$ & $\operatorname{ab9722(61)~}$ \\
\hline Rabbit polyclonal anti IL10 & Abbiotec (San Diego, CA, USA) & $1: 100$ & $250713(62)$ \\
\hline Rabbit polyclonal anti TGF $\beta$ & Santa Cruz (Dallas, TX, USA) & $1: 250$ & sc-90 (63) \\
\hline Goat polyclonal anti ChAT & AbD Serotec (Kidlington, UK) & $1: 200$ & $2080-0000(64)$ \\
\hline Rabbit antiserum SLURP-1 & Yasuhiro Moriwaki (Tokyo, JPN) & $1: 200$ & $(44)$ \\
\hline Goat polyclonal anti Chrna7 & Abcam (Cambridge, UK) & $1: 100$ & ab110851 (65) \\
\hline Rabbit polyclonal anti HIF1 $\alpha$ & Novus biologicals (Centennial, CO, USA) & $1: 400$ & NB100-479 (66) \\
\hline Cy3-conjugated $F\left(a b{ }_{2}\right.$ fragment donkey anti-rabbit lgG, polyclonal & Dianova (Hamburg, Germany) & $1: 200$ & $711-166-152(67)$ \\
\hline Cy3-conjugated $\mathrm{F}\left(\mathrm{ab}{ }^{\prime}\right)_{2}$ fragment donkey anti-goat lgG, polyclonal & Dianova (Hamburg, Germany) & $1: 200$ & $705-166-147(67)$ \\
\hline FITC-Avidin & Vector laboratories (Burlingame, CA, USA) & $1: 5000$ & $(68)$ \\
\hline
\end{tabular}

$20 \mathrm{ng} / \mathrm{ml}$ interleukin 3 [IL3] and stem cell factor [SCF]) to a final dilution of 500000 cells $/ \mathrm{ml}$ to generate cMC. Cells were cultured at $37^{\circ} \mathrm{C}$ and $5 \% \mathrm{CO}_{2}$. After 2 days, medium was added according to the cell density. Medium was changed and adapted to cell density once per week thereafter.

\section{Peritoneal Lavage Derived cMC}

On the day of harvesting, mice were deeply anesthetized and killed as described above. Abdominal skin was cleaned with 70\% ethanol and an incision was made into the ventral skin, paying great attention to preserve an intact peritoneum. Using a sterile syringe, $5 \mathrm{ml}$ of air and $5 \mathrm{ml}$ of $\mathrm{NaCl}$ were injected into the peritoneal cavity. Mice were then gently shaken for at least $5 \mathrm{~min}$ and the peritoneal lavage was collected with a fresh syringe and centrifuged at $1,000 \mathrm{rpm}$ for $10 \mathrm{~min}$ at $4^{\circ} \mathrm{C}$. The supernatant was removed and cells were resuspended with cMC medium (RPMI medium containing: $10 \%$ fetal calf serum [FCS], $1 \%$ penicillinstreptomycin [Pen/strep], $0.001 \% \alpha$-Monothioglycerol [MTG]) to a final dilution of 500,000 cells/ml. cMC were cultured at $37^{\circ} \mathrm{C}$ and $5 \% \mathrm{CO}_{2}$ with regular medium additions or changes as published previously (70).

\section{Verification of $\mathrm{cMC}$ Generation}

To verify cMC identity and degree of purity of cell cultures, cMC cytospins were prepared from both bone marrow and peritoneal lavage originating cell cultures. Cytospins were submitted to Giemsa staining and microscopic analysis of cell reactivity and morphology was performed to identify cMC. In addition to the Giemsa staining, cMC presence was also verified by cMC cytospin staining for the MC specific receptor CD117 in double staining with the unspecific MC marker FITCAvidin (Figure 1). Staining yield was quantified with the help of an ocular grid, counting stained cells in a minimum of 10 microscopic fields per cytospin. On average, we counted $80.40 \%$ cMC.

\section{$\beta$-Hexosaminidase Degranulation Assay}

cMC degranulation was assessed in bone marrow derived cMC after 4-6 weeks of culture. They were first sensitized with $1 \mu \mathrm{g} / \mathrm{ml}$
anti-DNP IgE for $1 \mathrm{~h}$. For activation, 100.000 cells/Eppendorf tube were challenged with different stressors and stimulators for $30 \mathrm{~min}$ as detailed in Table 3. After that, $50 \mu \mathrm{L}$ of supernatant or cell lysate and $50 \mu \mathrm{L}$ of p-NAG ( $1 \mathrm{mM}$ 4-Nitrophenyl $\mathrm{N}$-acetyl- $\beta$-D-glucosaminide in $0.1 \mathrm{M}$ Sodium Citrate buffer, $\mathrm{pH}$ 4.5) were added to each well of a flat bottom 96-well plate. Color was developed for $90 \mathrm{~min}$ at $37^{\circ} \mathrm{C}$. The reaction was stopped by adding $100 \mu \mathrm{L}$ of Sodium Carbonate buffer ( $50 \mathrm{mM} \mathrm{Na} 2 \mathrm{CO}_{3} / \mathrm{NaHCO}_{3}, \mathrm{pH}$ 10.7). Finally, the absorbance at $405 \mathrm{~nm}$ was measured in a microplate reader (TriStar LB 941 Multimode Microplate Reader) both in the supernatant and in the cell lysate.

Cells were resuspended and washed in a HEPES-Tyrodes buffer (1,000 ml containing: $135 \mathrm{mM} \mathrm{NaCl}, 5 \mathrm{mM} \mathrm{KCl}, 1 \mathrm{mM}$ $\mathrm{MgCl}_{2}, 1.8 \mathrm{mM} \mathrm{CaCl}_{2}, 5.6 \mathrm{mM}$ glucose, $20 \mathrm{mM} \mathrm{HEPES}$, and $0.05 \% \mathrm{BSA}$ ) and lysed through freezing them in $-80^{\circ} \mathrm{C}$ for $15 \mathrm{~min}$. The percentage of the $\beta$-hexosaminidase release was calculated using the following formula:

$$
\begin{gathered}
\% \beta-\text { hexosaminidase release }=\text { absorption supernatant } / \\
\text { (absorption supernatant }+ \text { absorption lysed cells) }
\end{gathered}
$$

Doses for stimulant usage in the respective experiments were either determined by pre-tests or taken from literature. SLURP-1 doses of $0.5 \mathrm{ng} / \mathrm{ml}, 5$ and $50 \mathrm{ng} / \mathrm{ml}$ were tested and yealded the best reproducible effects on cMC with $5 \mathrm{ng} / \mathrm{ml}$ of SLURP-1 while $0.5 \mathrm{ng} / \mathrm{ml}$ had very little effect and $50 \mathrm{ng} / \mathrm{ml}$ had toxic effects (not shown). SP doses were used according to literature (71). The NGF dose was chosen according to manufacturer's recommendations and the literature (72). Stimulation time of $30 \mathrm{~min}$ was chosen according to literature (71).

\section{cMC Culture With Stimulators of Cytokine Production}

On day 11 in culture, peritoneal lavage derived cMC were seeded in 6-wells plates at a density of 100,000 cells/100 $\mu \mathrm{l}$ and treated with different stressors and stimulators for 2, 8, 24, and $32 \mathrm{~h}$ as detailed in Table 4. After treatment, cells were collected for RNA isolation and supernatants were 

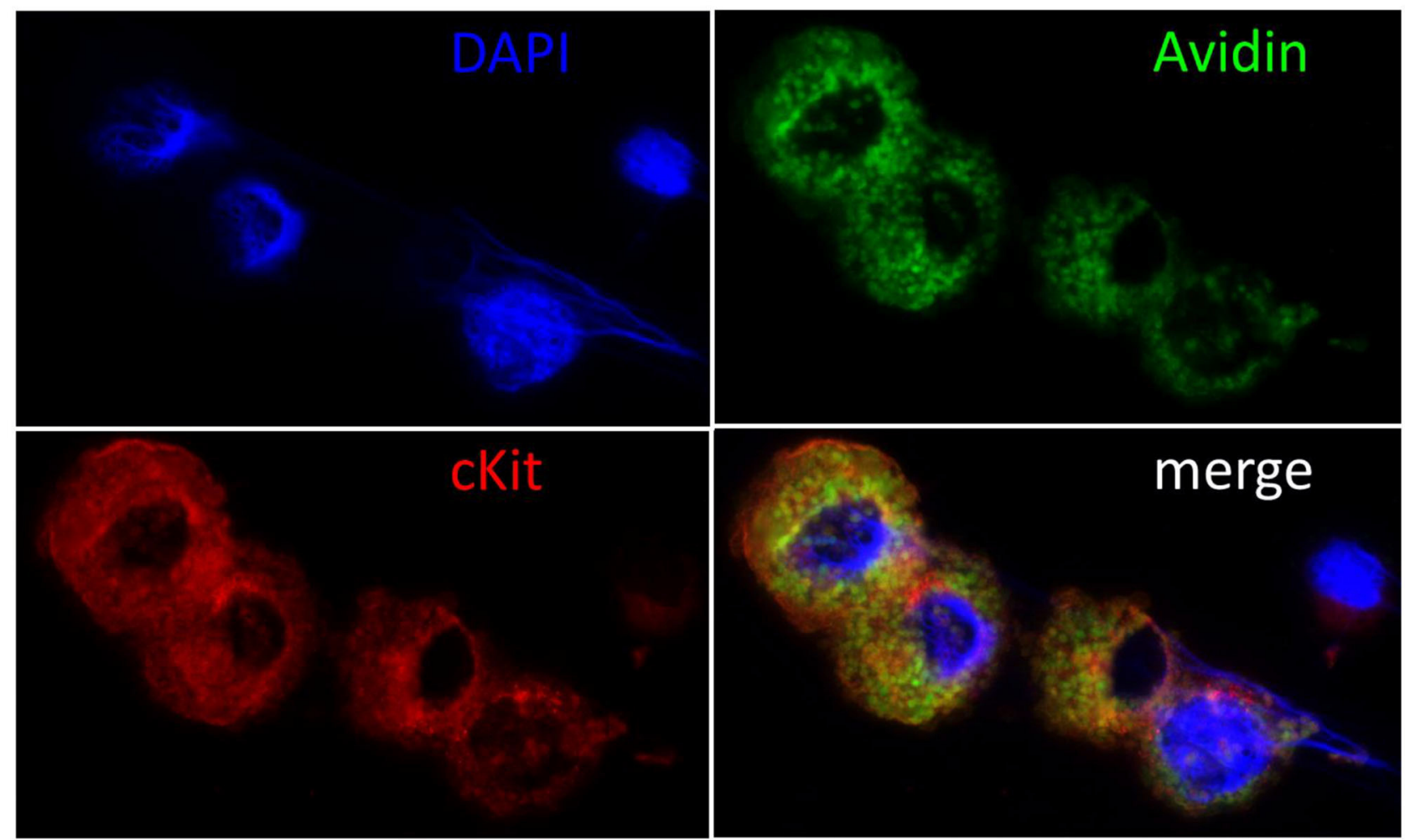

FIGURE 1 | Immunohistochemical confirmation of cMC. Cell nuclei were counterstained blue with DAPI (4',6-Diamidin-2-phenylindol), MC green with Fluorescein Avidin D (FITC-Avidin) and red with c-Kit staining as described previously $(6,68)$. Note the large cell nuclei and the intact cytoplasm packed with granules in the double reactive $\mathrm{cMC}$ and the small nucleus and narrow rim of cytoplasm surrounding the unstained cell, who's morphology suggests it to be a lymphocyte. The majority of c-Kit negative cells showed this morphology prior to cell culture and were lost in passaging.

TABLE 3 | Stimulants used in the $\beta$-hexosaminidase degranulation assay (HDA).

\begin{tabular}{|c|c|c|c|}
\hline Stimulant & Concentration & $\begin{array}{l}\text { Incubation } \\
\text { time }\end{array}$ & Company \\
\hline SLURP-1 & $0,5 \mathrm{ng} / \mathrm{ml} ; 5 \mathrm{ng} / \mathrm{ml}$ & $30 \mathrm{~min}$ & $\begin{array}{l}\text { Abnova } \\
\text { (Heidelberg, GER) }\end{array}$ \\
\hline Substance P & $10 \mu \mathrm{M}$ & $30 \mathrm{~min}$ & $\begin{array}{l}\text { Sigma-Aldrich } \\
\text { (München, GER) }\end{array}$ \\
\hline $\begin{array}{l}\text { Nerve growth } \\
\text { factor (NGF) }\end{array}$ & $50 \mathrm{ng} / \mathrm{ml}$ & $30 \mathrm{~min}$ & $\begin{array}{l}\text { Promega } \\
\text { (Madison, WI, USA) }\end{array}$ \\
\hline $\begin{array}{l}\text { Albumin, } \\
\text { dinitrophenyl, } \\
\text { (DNP-HSA) }\end{array}$ & $30 \mathrm{ng} / \mathrm{ml}$ & $30 \mathrm{~min}$ & $\begin{array}{l}\text { Sigma-Aldrich } \\
\text { (München, GER) }\end{array}$ \\
\hline Ionomycin & $1 \mu \mathrm{M}$ & $30 \mathrm{~min}$ & $\begin{array}{l}\text { Sigma-Aldrich } \\
\text { (München, GER) }\end{array}$ \\
\hline $\begin{array}{l}\text { Phorbol } \\
\text { 12-myristate } \\
\text { 13-acetate (PMA) }\end{array}$ & $10 \mathrm{nM}$ & $\begin{array}{l}30 \text { min } \\
\text { co-incubation } \\
\text { with lonomycin }\end{array}$ & $\begin{array}{l}\text { Sigma-Aldrich } \\
\text { (München, GER) }\end{array}$ \\
\hline
\end{tabular}

collected for ELISA analysis. All materials were stored at $-80^{\circ} \mathrm{C}$ until further analysis. Cells were also utilized for cMC identification using cytospin followed by Giemsa and cKit staining.
TABLE 4 | Stressors and stimulators used in cMC cell culture.

\begin{tabular}{|c|c|c|c|}
\hline Stimulants & Concentrations & Incubation times & Company \\
\hline SLURP-1 & $5 \mathrm{ng} / \mathrm{ml}$ & $\begin{array}{l}2,8,24 \mathrm{~h} \\
8 \mathrm{~h} \text { pre-incubation } \\
\text { Prior to } 24 \mathrm{~h} \mathrm{IL} 1 \beta\end{array}$ & $\begin{array}{l}\text { Abnova } \\
\text { (Heidelberg, GER) }\end{array}$ \\
\hline $\begin{array}{l}\text { AR-R } 17779 \\
\text { hydrochloride } \\
\text { (Chrna7 agonist) }\end{array}$ & $10 \mu \mathrm{M}$ & $\begin{array}{l}2,8,24,32 \mathrm{~h} \\
8 \mathrm{~h} \text { pre-incubation } \\
\text { Prior to } \\
24 \mathrm{~h} \text { SLURP-1 }\end{array}$ & $\begin{array}{l}\text { TOCRIS (Bristol, } \\
\text { UK) }\end{array}$ \\
\hline IL1 $\beta$ & $5 \mathrm{ng} / \mathrm{ml}$ & $24 \mathrm{~h}$ & $\begin{array}{l}\text { PeproTech } \\
\text { (Hamburg, GER) }\end{array}$ \\
\hline $\begin{array}{l}\mathrm{PX}-4782 \mathrm{HCl} \\
\text { (HIF1 } \alpha \text { inhibitor) }\end{array}$ & $40 \mu \mathrm{M}$ & $\begin{array}{l}\text { 8h pre-incubation } \\
\text { Prior to } \\
24 \mathrm{~h} \text { SLURP-1 }\end{array}$ & $\begin{array}{l}\text { Selleckchem } \\
\text { (Boston, US) }\end{array}$ \\
\hline
\end{tabular}

The doses of AR-R 17779 hydrochloride and IL1 $\beta$ were taken from literature $(73,74)$. The dose of the HIF1 $\alpha$ inhibitor PX-478 $2 \mathrm{HCl}$ was chosen according to manufacturer's information.

\section{ELISA}

Supernatant culture medium of peritoneal lavage derived cMC was utilized for HIF1 $\alpha$ ELISA (IBL International, 
Hamburg, Germany) and were performed according to the manufacturer's protocol.

\section{Microarray Analysis}

RNA isolated from the mouse back skin biopsies of stressed and unstressed animals was utilized for microarray analysis as described previously (6).

\section{Dichlorofluorescein Diacetate (DCFH-DA) Assay}

Reactive oxygen species (ROS) generation was assessed by performing a DCFH-DA assay using bone marrow derived cMC. cMC were first washed and resuspended in the HEPES-Tyrodes buffer (buffer without FCS, phenol red and antibiotics) to a final dilution of 100,000 cells/100 $\mu \mathrm{l}$. Cells were seeded in a black flat bottom 96-well plate and treated with different stressors and stimulators for $30 \mathrm{~min}$ as detailed in Table 5. After $30 \mathrm{~min}, 20 \mu \mathrm{M}$ DCFH-DA (Sigma-Aldrich, München, Germany) was added and cells were incubated for another $30 \mathrm{~min}$ at $37^{\circ} \mathrm{C}$ in the dark. Afterwards, cells were washed and DCFH-DA fluorescence was measured at $1,3,5$, and $24 \mathrm{~h}$ after DCFH-DA adding, using a fluorescence microplate reader (Mithras LB 940 Multimode Microplate Reader) with excitation and emission of $485 \mathrm{~nm}$ and $535 \mathrm{~nm}$.

\section{Statistics}

To fulfill the $\mathrm{R}$ principles for the harmonization of science and ethics in the field of animal experimentation, we aimed to keep the number of mice required for the experiments as low as possible. Based on our previous experiences with exploratory animal studies, we presumed that the assumption of normality may not be fulfilled during the estimation of sample size and nonparametric methods were chosen. Alternative hypotheses were tested as two-sided tests for equality with a significance level of 0.05 , and the power was calculated by $G *$ Power 3.1 as for example described in (75). This resulted in an $N=5$ for a small effect sizes of 0.2 and $N=3$ for 0.1 . Therefor all experiments were performed with an $N=3-5$ per group as indicated in the figures.

GraphPad Prism 6 software (GraphPad Software: La Jolla, US) was used for all other data processing. After testing for normality with the Shapiro-Wilk test, statistical differences between the averages of the control and the stress treated groups and between groups in cMC culture experiments were determined nonparametrically by Mann-Whitney $U$-test if only two groups were involved or Kruskal-Wallis test with post hock pairwise comparisons using Dunn's multiple comparisons tests if more than one group was involved. Means and SEM are shown, $p \leq$ 0.05 was interpreted as significant. HM and mRNA data were submitted to a Spearman's rank correlation (Spearman's rho).

\section{RESULTS}

\section{Noise Stress Exposure Increases Cutaneous Chrna7 and SLURP-1 mRNA}

Reportedly, adverse psychotoxic noise stress effects are prominent in skin $48 \mathrm{~h}$ after termination of a $24 \mathrm{~h}$ noise-stress
TABLE 5 | Stimulants used in the DCFH-DA assay.

\begin{tabular}{|c|c|c|c|}
\hline Stimulants & Concentrations & $\begin{array}{l}\text { Incubation } \\
\text { times }\end{array}$ & Company \\
\hline $\begin{array}{l}\text { AR-R } 17779 \\
\text { hydrochloride } \\
\text { (Chrna7 agonist) }\end{array}$ & $10 \mu \mathrm{M}$ & $30 \mathrm{~min}$ & $\begin{array}{l}\text { TOCRIS } \\
\text { (Bristol, UK) }\end{array}$ \\
\hline Substance P & $10 \mu \mathrm{M}$ & $30 \mathrm{~min}$ & $\begin{array}{l}\text { Sigma-Aldrich } \\
\text { (München, GER) }\end{array}$ \\
\hline
\end{tabular}

exposure (4, 6, 36). We analyzed cholinergic parameters in full thickness skin samples from mice exposed to $24 \mathrm{~h}$ of noise stress $48 \mathrm{~h}$ after stress exposure (Figure 2). We found that the levels of $\mathrm{ACh}$ and choline as measured in skin extracts were unchanged (Figures 2A,B). Accordingly, the mRNA expression of presynaptic cholinergic markers responsible for $\mathrm{ACh}$ and choline synthesis (ChAT, VAChT, Oct3) were unchanged after noise stress, as was the expression of digesting cholinesterases (AChE and BChE) (Figures 2C-O). However, the mRNA levels of SLURP-1 and Chrna7 were significantly upregulated by noisestress exposure (Figures $\mathbf{2} \mathbf{C}, \mathbf{H}-\mathbf{J}$ ). No other receptor subtypes (Chrna9, Chrm3) and Chrna modulators (Lynx1, SLURP-2) were changed.

\section{Nerve Fibers and MC Are Source and Target of SLURP-1 and Chrna7 SLURP-1 and Chrna7 Are Expressed at the sMC-Nerve Fiber Interface}

To determine the skin's target structures for stress-induced CS regulation of Chrna7 and its endogenous peptidergic ligand SLURP-1, we next employed IHC of full thickness skin samples cryo-conserved $48 \mathrm{~h}$ after a $24 \mathrm{~h}$ noise-stress exposure. This approach allows the study of psychotoxic stress effects in situ. Full thickness tissue samples taken from stressed experimental animals are best suited to show the stress-responses of the cells, while they are embedded in their connective tissue and in their natural vascular and neuronal environment. This approach revealed prominent expression of SLURP-1 and Chrna7 in nerve fibers and sMC and suggested they are source and target of CS-stress effects in healthy skin (Figures 3A-D). In addition, a weak expression of SLURP-1 was found in the basal layer of the epidermis, but immunoreactivity of other immune cells, including the suprabasally located Langerhans cells or dermal macrophages and lymphocytes, could not be detected.

SLURP-1-immunoreactive nerve fibers showed the characteristic beads-on-a-string like morphology of peptidergic nerve fibers, as described previously with neuronal markers like PGP 9.5 and neuropeptides such as SP $(44,55,56,76)$. They were frequently found in the subcutis, but also abundant subepidermally, in the innervation of arrector pili muscles and around hair follicles. Close contacts between SLURP$1+$ nerve fibers and sMC were most prominent in stressed mice at the dermis-subcutis border and often looked as if the nerve fibers were embracing the sMC. Also primarily in 

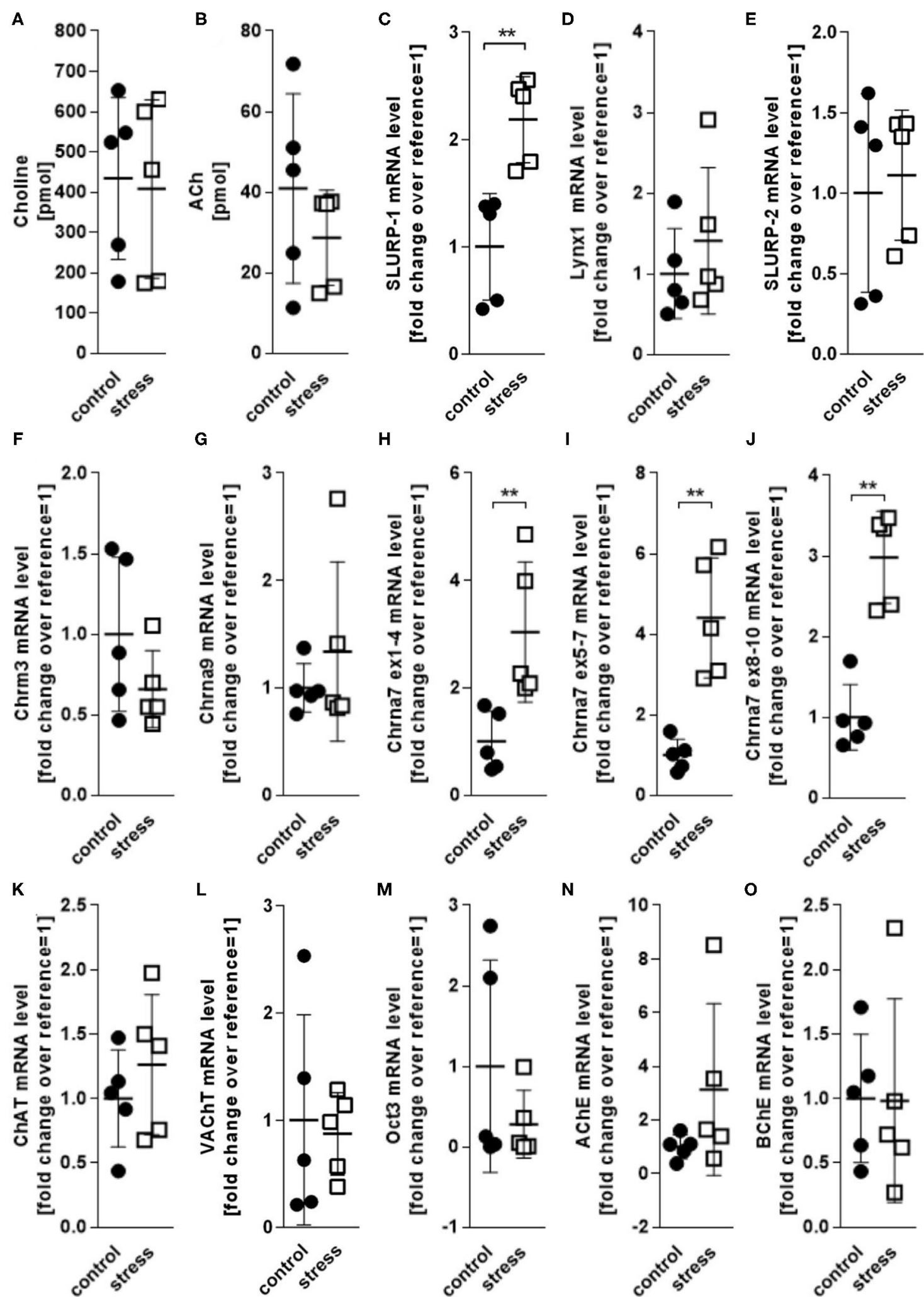

FIGURE 2 | HPLC and qPCR levels of key CS markers detected in full thickness skin samples obtained from control and $24 \mathrm{~h}$ noise-stressed mice. $P$ < $0.001=$ ** Note, that Chrna7 was analyzed with three different primers, targeting exons 1-4, 5-7, and 8-10, respectively, to assess different expression patterns of possible splice variants (51). All three primers yielded the same results. Each dot in the graphs represents one mouse. ACh, acetylcholine; AChE, acetylcholineesterase; BChE, butyrylcholinesterase; ChAT, cholineacetyltransferase; Chrm3, muscarinic acetylcholine receptor 3; Chrna, alpha nicotinic acetylcholine receptor; Lynx1,

Ly6/neurotoxin 1; Oct3, organic cation transporter 3; SLURP, secreted Ly-6/uPAR-related protein; VAChT, vesicular acetylcholine transporter. 

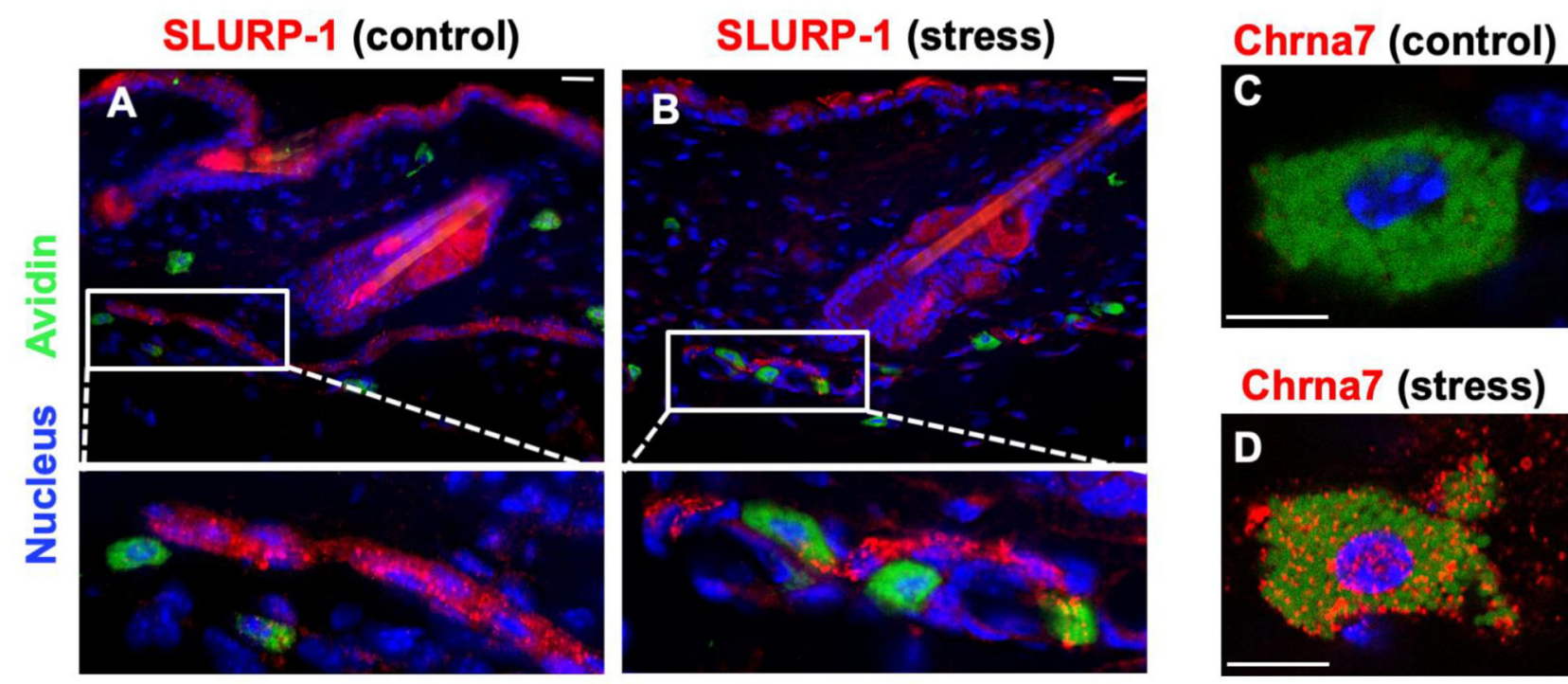

\section{Chrna7 (stress)}
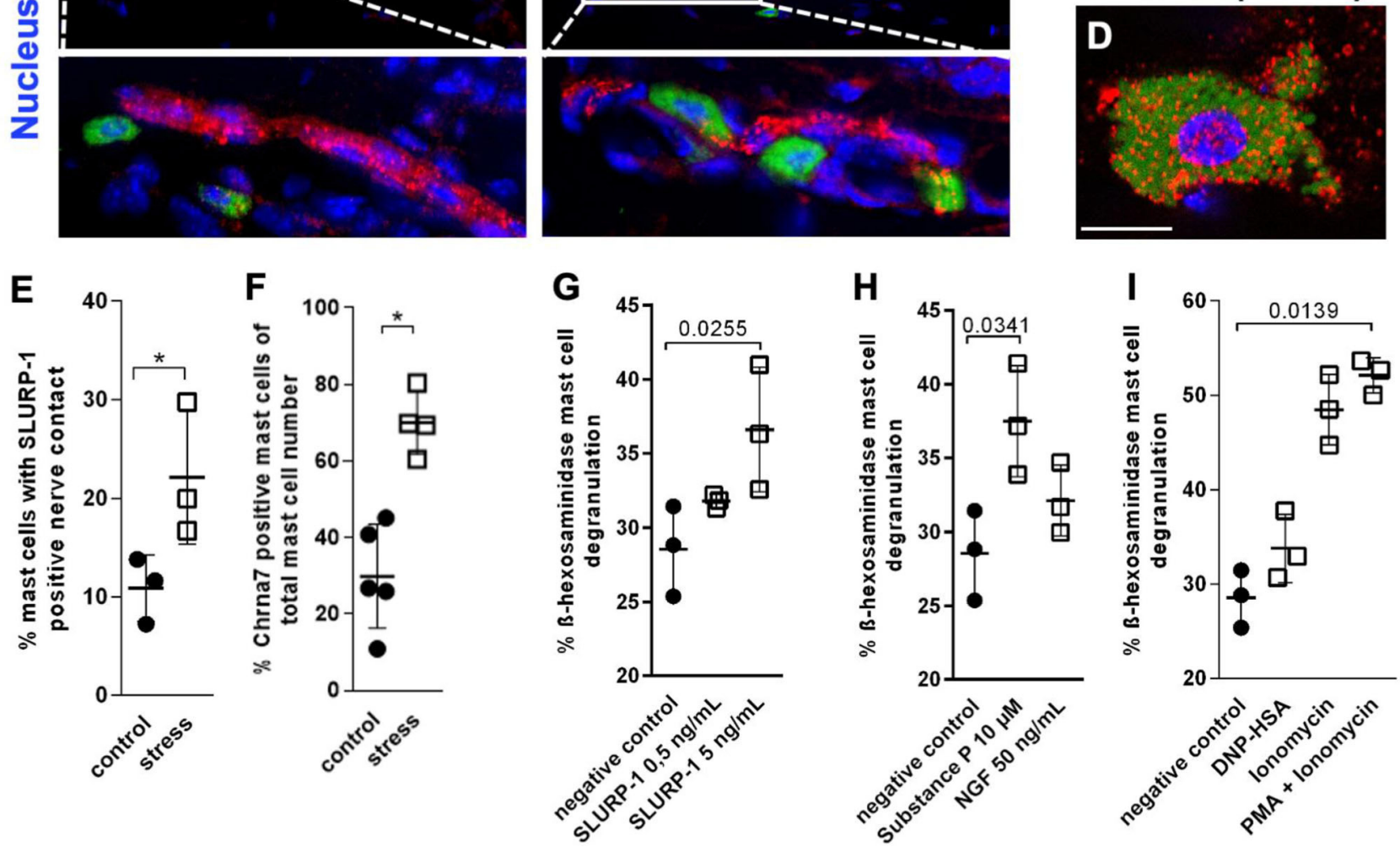

FIGURE 3 | MCs are targets of SLURP-1 in the skin. (A-D) immunohistology and (E,F) HM of Chrna7 and SLURP-1 in full-thickness skin samples obtained from control and $24 \mathrm{~h}$ noise-stressed mice. In photomicrographs, sMC are labeled green, Chrna7 and SLURP-1 red. Each dot in the graphs represents one mouse. (G-I) cMC stimulation with SLURP-1 yielded comparable results to stimulation with the stress mediator SP and standard MC degranulators DNP-HSA, lonomycin, lonomycin and PMA. $P<0.01={ }^{*}$. Scale bars: (A,B) $25 \mu \mathrm{m}$ and (C,D) $10 \mu \mathrm{m}$. Chrna, alpha nicotinic acetylcholine receptor; DNP-HSA, Dinitrophenyl Albumin; NGF, Nerve Growth Factor; PMA, Phorbol 12-myristate 13-acetate; SLURP, secreted Ly-6/uPAR-related protein.

stressed mice, Chrna7+ sMC showed a granular cytoplasmatic staining pattern indicating a vesicular staining (Figures 3C,D). This suggested increased neuro-immune interaction between SLURP-1 peptidergic nerve fibers and MC in stressed mice.

$\mathrm{HM}$ was used for the quantification of these nerve fiber contacts with MC and MC-Chrna7 expression. This approach confirmed significantly more contacts between SLURP-1+ nerve fibers and sMC in the skin of noise-stressed mice (Figure 3E). At the same time, the percentage of Chrna7+ sMC was increased after stress exposure (Figure 3F), but the percentage of $\mathrm{ChAT}+\mathbf{s M C}$ or the total number of $\mathbf{s M C}$ was unchanged (data not shown).

\section{SLURP-1 Degranulates cMC}

Corresponding to the frequent SLURP-1+ nerve fiber contacts with sMC in stressed skin, higher doses of SLURP-1 $(5 \mathrm{ng} / \mathrm{ml})$ degranulated cMC, whereby SLURP-1 had an effect comparable to the classical stress-MC degranulator SP and stronger than NGF, but was less capable to induce degranulation than the combination of the potent MC degranulators PMA and Ionomycin (Figures 3G-I). This adds SLURP-1 to the list of peptides that act as stress-MC degranulators. As it is localized in peripheral nerve fibers with peptidergic morphology and modulates the function of a neurotransmitter receptor it may be considered as a neuropeptide in this context. 


\section{Pro-inflammatory MC Cytokines Are CS Regulated \\ IL1 $\beta$ sMC Expression Is Enhanced by Stress and by SLURP-1 Under Inflammatory Conditions}

To learn if SLURP-1 and Chrna7 regulate MC's cytokine production after stress exposure in addition to the observed MC degranulation, we next aimed to identify potential targetcytokines by immunohistochemistry in full thickness skin biopsies from control and $24 \mathrm{~h}$ noise stressed mice. This revealed prominent IL $1 \beta$ expression in sMC $48 \mathrm{~h}$ after a $24 \mathrm{~h}$ noise stress exposure as well as expression of $\mathrm{TNF} \alpha-$, IL10-, or TGF $\beta$ by sMC both in control and stressed skin (Figures 4A-D). HM of the cytokine-positive sMC revealed a significant increase in the percentage of IL1 $\beta$ - but not TNF $\alpha$-, IL10-, or TGF $\beta$ immunoreactive sMC in stressed mice (Figures $4 \mathrm{E}-\mathrm{H}$ ).

With this in mind, we expected SLURP-1 to enhance IL1 $\beta$ production. However, in WT cMC, SLURP-1 had only a mild and non-significant effect on cytokines and upregulated primarily TNF $\alpha$ mRNA (Figure 4I). This contrasted the downregulation of TNF $\alpha$ mRNA by the Chrna7 agonist AR-R 17779, which was comparable to the increase in TNF $\alpha$ mRNA in cMC from Chrna7-KO mice and did not occur when AR-R 17779 was given together with SLURP-1. SLURP-1 did thus not act as a Chrna7 ligand but rather as a blocker of Chrna7 downregulation of TNF $\alpha$ (Figures 4J-L). Interestingly, SLURP-1 dramatically upregulated IL1 $\beta$ in cMC from Chrna7-KO suggesting that SLURP-1 effects on IL1 $\beta$ are blocked by Chrna7 signaling. However, WT cMC stimulation with SLURP-1 in the presence of IL1 $\beta$ resulted in a dramatic upregulation of IL1 $\beta$ indicating that SLURP-1 effects on IL1 $\beta$ are not blocked by Chrna7 signaling under stress-induced inflammatory conditions (Figures $4 \mathbf{M}, \mathbf{N}$ ).

\section{HIF1 $\alpha$ and Oxidative Stress Are Intermediaries Between SLURP-1 and IL1 $\beta$ Upregulation}

To learn more about intermediaries between SLURP-1 and cytokine regulation in $\mathrm{MC}$ in response to stress, we next studied inflammatory transcription factors focussing on two transcription factors potentially regulated by SLURP-1 and Chrna7: HIF1 $\alpha$ (77-79) and STAT3 (80). Reassessing our previously published microarray, which compared skin samples derived from control with samples from stressed mice (6), we found that HIF1 $\alpha$ was upregulated in stressed skin compared to control (fold change 0.414 and STAT3 was downregulated (fold change -0.996). qPCR of full thickness skin samples confirmed this observation for HIF1 $\alpha$ but revealed stable levels for STAT3 (Figure 5A). To assess if MC were the source of HIF1 $\alpha$ production, we again employed HM and found HIF1 $\alpha$ expression in sMC in a granular pattern (Figure 5B) mostly at the dermissubcutis border. We also found higher numbers of HIF $1 \alpha+$ sMC in stressed mice (Figure $5 \mathrm{C}$ ).

To test the potential CS regulation of HIF1 $\alpha$ transcription, we employed cMC and found that only the Chrna7 agonist ARR 17779 but not SLURP-1 or Chrna7-KO upregulated HIF1 $\alpha$ mRNA and protein (Figures 5D,E). Since it is known that HIF1 $\alpha$ activity can be enhanced by ROS (81), that stress increases
ROS (82), that and $\mathrm{H}_{2} \mathrm{O}_{2}$ regulates nicotine-induced $\mathrm{HIF} 1 \alpha$ expression via Chrna7-mediated signaling pathways (78), we wanted to know whether ROS are involved in the observed regulation. We therefore used a DCF-DA assay to measure intracellular $\mathrm{H}_{2} \mathrm{O}_{2}$ and found that AR-R 17779 had a lasting stimulatory effect on ROS production in cMC. We also confirmed the reported SP upregulation of ROS (Figure 5F). However, this effect was rather short lived. To finally learn if the HIF $1 \alpha$ induction by Chrna7 interacts with SLURP-1 effects, we studied SLURP-1 effects in cMC after HIF1 $\alpha$ blockade. This approach led to a significant TNF $\alpha$ and IL1 $\beta$ increase by SLURP-1 (Figure 5G).

Finally, to assess whether the observed upregulations relate to each other, sMC HM and mRNA data were submitted to a Spearman's rank correlation. We found that upregulation of CS components Chrna7 and SLURP-1, as well as of IL1 $\beta$ and HIF1 $\alpha$ significantly correlated with each other (Table 6). These findings support a strong connection of these components in stress.

\section{DISCUSSION}

The here present experiments aim to clarify the CS involvement in inflammatory stress responses of the healthy organism in an established experimental stress paradigm. Our results first revealed a highly selective upregulation of individual components of the CS in healthy mouse skin in response to a $24 \mathrm{~h}$ noise stress exposure, namely Chrna7 and its peptidergic modulator SLURP-1. With respect to neuroimmune communication, immunohistochemistry located these two markers primarily to sMC and nerve fibers that were located close by the sMC in the skin of stressed mice. This suggested a role of their interaction in neurogenic inflammation, as was previously described for sensory neuropeptides such as SP (36). $\mathrm{MC}$ were next confirmed as relevant cellular targets of the skin's CS stress response because SLURP-1 was able to degranulate cMC. In addition, it promoted cMC cytokine production in favor of an innate pro-inflammatory state. We hence show for the first time that SLURP-1 is a MC degranulating peptide and that it is used by the CS to contribute to stress-MC activation. The thus supported pro-inflammatory state is well-suited to contribute to efficient host defense and maintain homeostasis in healthy skin.

That the CS does not play its expected anti-inflammatory role in stressed healthy skin is intriguing for a number of reasons and requires in depth discussion, as it contrasts the anti-inflammatory cholinergic axis concept. This can have widespread implications for skin pathologies ranging from allergies via infectious diseases to tumor development $(9,33,36)$.

For one, the previously published suggestive evidence for an anti-inflammatory effect of SLURP-1 in skin disease and allergy was strong. Individuals with a mutation that disrupts SLURP-1 function suffer from Mal de Meleda, a transgressive and progressive palmoplantar inflammatory disease resembling the effects of MC hyperactivation in atopic dermatitis $(83,84)$. Also, SLURP-1 is often considered to be an allosteric agonist of Chrna7 and such agonists were shown to inhibit MC degranulation (20). Moreover, SLURP-1 was detected in skin nerve fibers shortly after its first description in $1999(44,85,86)$ and close contacts 


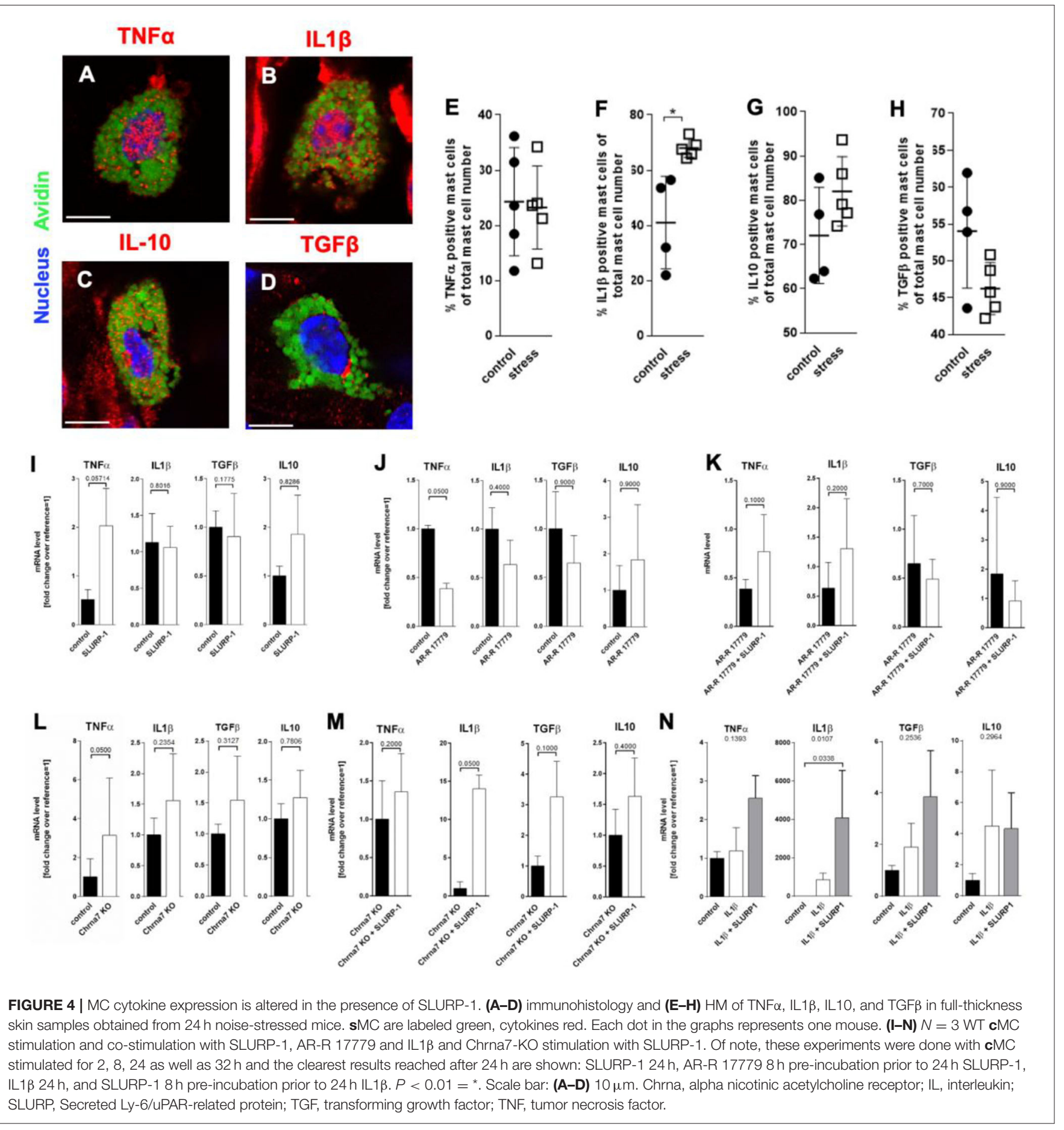

of calcitonine gene related peptide+ cholinergic nerve fibers with Chrna7+ MC were reported in a food allergy model, in which Chrna7 agonists attenuated MC hyperplasia and allergic inflammation (87).

For another, our results contrast a number of studies that clearly state an anti-inflammatory and hence classical Chrna7 agonistic effect of SLURP-1 in other tissues. Recombinant SLURP-1 decreased for example the TLR9-dependent secretion of IL- 8 by colonocytes, the IFN $\gamma$-induced upregulation of ICAM1 in enterocytes, the production of TNF $\alpha$ by T-cells, and the secretion of IL1 $\beta$ and IL6 by macrophages (88). These results supported the longtime accepted assumption that SLURP1 is an allosteric agonist of Chrna7 and promotes an antiinflammatory state.

Our study, however, supports the contrasting concept that close contacts of SLURP-1+ nerve fibers with sMC provide a 
A

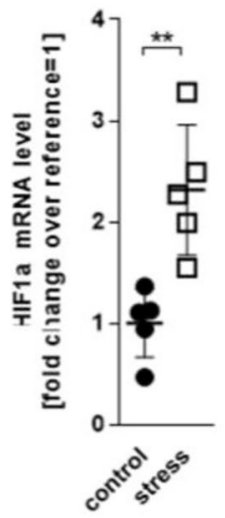

D

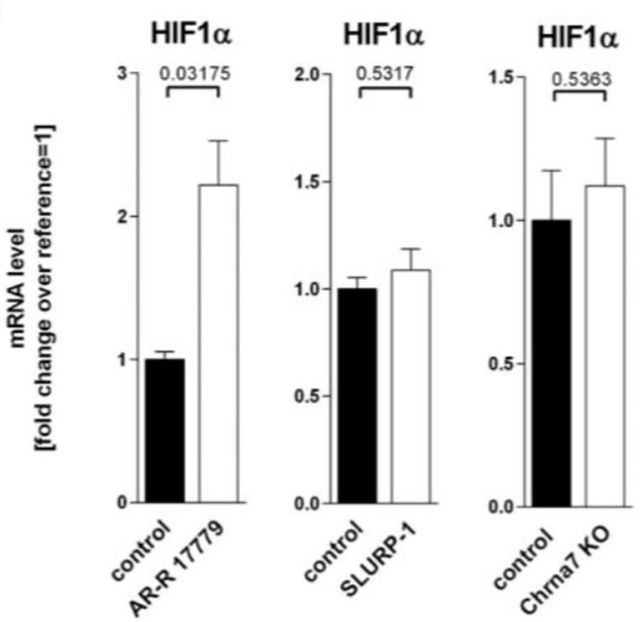

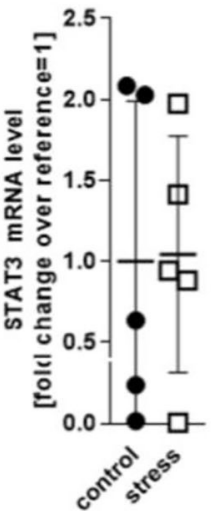
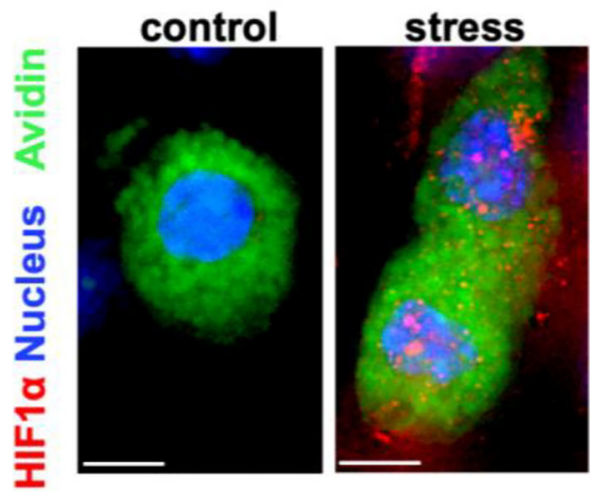

C

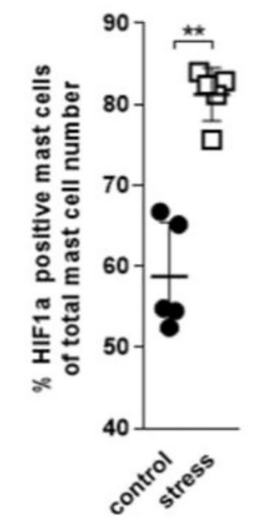

E

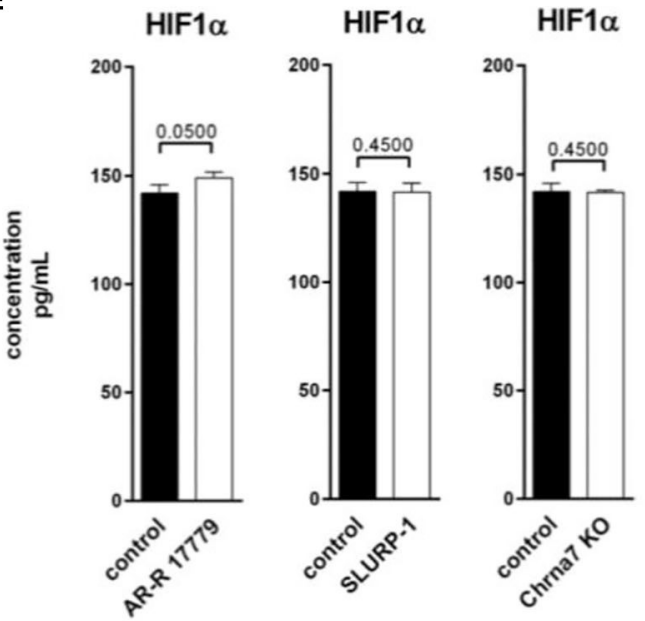

$\mathbf{F}$

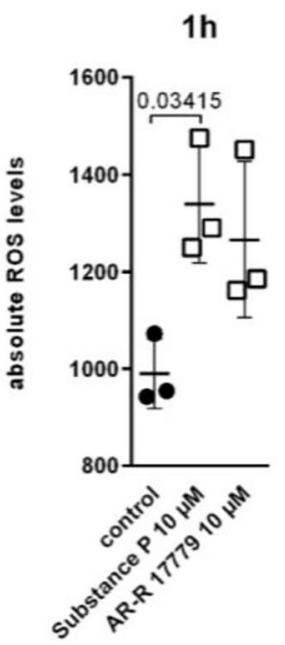

$3 h$

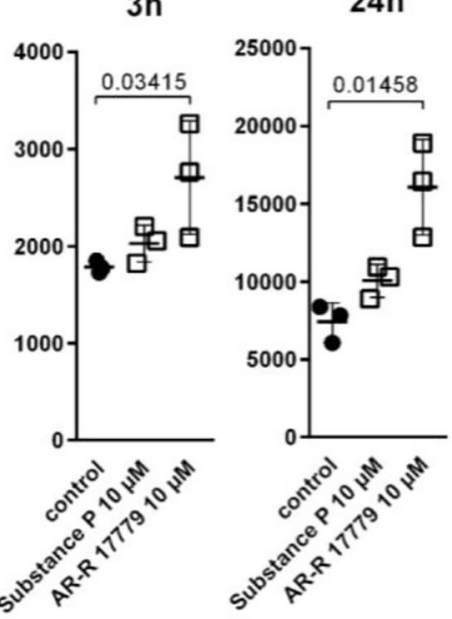

G

TNF $\alpha$

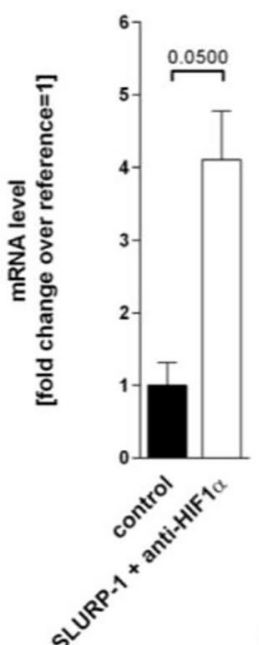

IL1 $\beta$
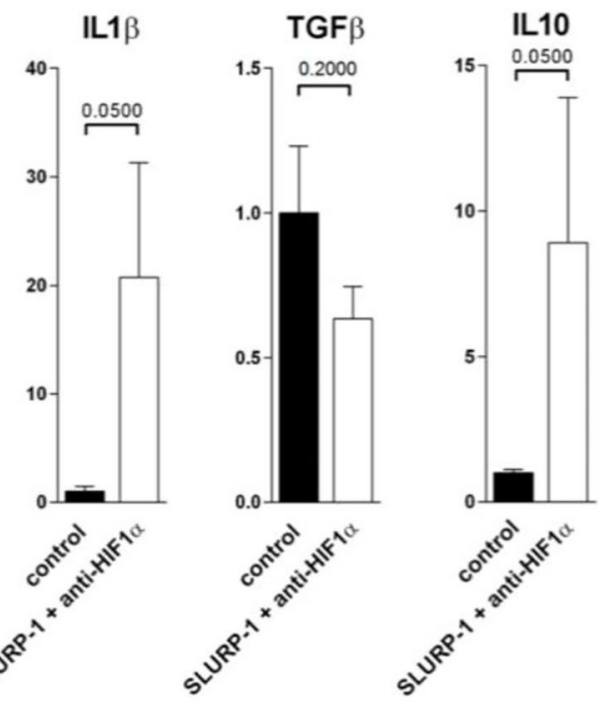

FIGURE 5 | ROS mediated HIF1 $\alpha$ upregulation inhibits TNF $\alpha$ production. (A) qPCR of HIF1 $\alpha$ and STAT3, (B) immunohistology, and (C) HM of HIF1 $\alpha$ in full-thickness skin samples obtained from control and $24 \mathrm{~h}$ noise-stressed mice. sMC are labeled green, HIF1 $\alpha$ red. (D,E) N=3 WT cMC stimulation with AR-R 17779 increased HIF1 $\alpha$ mRNA and protein while treatment with SLURP-1 or Chrna7 KO did not change levels compared with control. (F) absolute ROS levels measured after 1 , 3 , and $24 \mathrm{~h}$. wt $\mathbf{c M C}$ were stimulated with SP and AR-R 17779. Each dot in (A,C,F) represents one mouse. (G) $N=3$ WT cMC co-stimulation with SLURP-1 and a HIF1 $\alpha$ inhibitor. Results for AR-R $1777924 \mathrm{~h}$ and HIF1 $\alpha$ inhibitor $8 \mathrm{~h}$ pre-incubation prior to $24 \mathrm{~h}$ SLURP-1 are shown. $P<0.001={ }^{\star *}$. Scale bar: (B) $10 \mu \mathrm{m}$. HIF, hypoxia inducible factor; ROS, reactive oxygen species; STAT, signal transducer and activator of transcription; SLURP, Secreted Ly-6/uPAR-related protein. 
TABLE 6 | Spearman's rank correlation between sMC HM and mRNA data.

\begin{tabular}{|c|c|c|c|c|c|c|c|c|}
\hline & A & B & C & D & $\mathbf{E}$ & $\mathbf{F}$ & G & $\mathbf{H}$ \\
\hline \multicolumn{9}{|l|}{ A: \% Chrna7+ of total MC number $(N=5)$} \\
\hline B: \% MC with SLUPR-1 pos. nerve cont. $(N=3)$ & 0.900 & & & & & & & \\
\hline C: $\%$ IL $1 \beta+M C$ of total MC number $(N=4)$ & $0.833^{*}$ & $0.943^{*}$ & & & & & & \\
\hline D: $\% \mathrm{HIF} 1 \alpha+$ of total MC number $(N=5)$ & $0.883^{\star *}$ & 0.771 & $0.917^{\star \star}$ & & & & & \\
\hline E: Chrna7 1-4 mRNA level $(N=5)$ & 0.583 & 0.657 & 0.650 & $0.697^{\star}$ & & & & \\
\hline F: Chrna7 5-7 mRNA level $(N=5)$ & 0.650 & 0.657 & $0.700 *$ & $0.697^{\star}$ & $0.806^{\star *}$ & & & \\
\hline G: Chrna7 8-10 mRNA level $(N=5)$ & $0.733^{\star}$ & $0.886^{*}$ & 0.683 & $0.721^{*}$ & $0.794^{\star *}$ & $0.794^{\star \star}$ & & \\
\hline H: SLURP-1 mRNA level $(N=5)$ & $0.767^{\star}$ & 0.771 & $0.833^{\star \star}$ & $0.806^{\star \star}$ & $0.672^{\star}$ & $0.818^{\star *}$ & $0.660^{\star}$ & \\
\hline I: HIF1 $\alpha$ mRNA level $(N=5)$ & $0.800^{*}$ & 0.828 & $0.717^{*}$ & $0.721^{\star}$ & 0.588 & $0.830^{\star \star}$ & $0.806^{\star *}$ & $0.830^{* *}$ \\
\hline
\end{tabular}

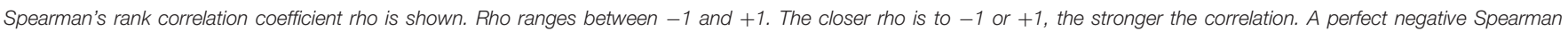
correlation is -1 , a perfect positive correlation is +1 . Statistically significant values are printed in bold and denotes the strength of the correlation. $P<0.05={ }^{*} . P<0.001={ }^{* \star}$. Chrna, alpha nicotinic acetylcholine receptor; HIF, hypoxia inducible factor; IL, interleukin; MC, mast cells; SLURP, secreted Ly-6/uPAR-related protein.

neurogenic circuit in stressed skin that can boost inflammatory processes by leading to MC degranulation and pro-inflammatory cytokine production $(7,16)$. It is possible that these proinflammatory effects of SLURP-1 are due to its inhibition of Chrna7 signaling or the desensitization of Chrna7 to its agonists (89-93). This concept is supported by the

report that the exposure of Chrna7+ Xenopus oocytes to recombinant SLURP-1 leads to a non-competitive inhibition of the response to acetylcholine (94). Moreover, SLURP-1 was found to antagonize biological functions attributed to Chrna7 in patients with pancreatic cancer (95) or malignant melanoma (96). In skin plagued by an inflammatory disease this pro-inflammatory effect could hence have deleterious effects and worsen inflammation, while it could protect from cancer progression and potentially viral infections in other contexts $(33,41,97)$.

Notably, MC can produce and release cytokines selectively and acute stress can promote the transient production and release of these pro-inflammatory cytokines (98). Cytokines that regulate innate and adaptive immune responses such as IL1 $\beta$ or TNF $\alpha$ are thereby de novo synthesized and released independently from degranulation-associated signaling pathways (99), as shown for example in the late phase of MC activation induced by the high-affinity receptor for IgE (Fc epsilon RI) (20, 21).

That we found high IL1 $\beta 48 \mathrm{~h}$ after noise stress and that SLURP-1 enhanced IL1 $\beta$ in cMC under certain conditions, while Chrna7 was unable to downregulate $\mathrm{TNF} \alpha$ in combination with SLURP-1, is intriguing. In the pathophysiology of inflammatory diseases Chrna7-mediated downregulation of $\mathrm{TNF} \alpha$ is widely studied and its respective anti-inflammatory benefits are appreciated in a number of highly acute inflammatory disease states, but clinical effects of Chrna7 targeting treatments do not always bring the expected beneficial results (89-93). Our results imply that it is important to control for SLURP-1 in respective settings. Also, further studies are required to address the interaction of SLURP-1 with other Chrna.

Current studies suggest that SLURP-1 can be a ligand of Chrna9 (100), which was shown to be upregulated in the absence of Chrna7 $(101,102)$. Interestingly, the specific Chrna7 antagonist MG624 was lately shown to also act on Chrna9 containing hetero-pentamers in cancer cells (103). Since Chrna9 was shown to be involved in the inhibition of the release of IL1 $\beta$ in response to the danger signal extracellular ATP (104), the here reported IL1 $\beta$ upregulation in Chrna7-KO mast cells after stimulation with SLURP-1 could be mediated by SLURP-1 interference with Chrna9.

Overall, it would be interesting to learn, what role plays SLURP-1 in the NLRP3 inflammasome induced release of IL1 $\beta$ as this was recently shown to be present in MC (105) and to be attenuated by classical Chrna7 activation in a stroke model (106). Regulation of NLRP3 inflammasome activation could represent a target for future pharmacologic interventions employing SLURP1. This is especially interesting in chronic inflammatory skin and allergic diseases (107) that reportedly are stress-sensitive and involve NLRP3 inflammasome activation such as psoriasis (108), contact hypersensitivity (109) or asthma (110). In fact, in a microarray analysis employing the Affymetrix Mouse Genome 430A 2.0 Array that we had performed in another project (6), we had previously observed the as yet unreported upregulation of Asc (1.280-fold) and Casp1 (0.397-fold). Since IL1 $\beta$ can boost inflammatory diseases associated with IL1 $\beta$ overexpression (111-113) the possibility to regulate IL1 $\beta$ levels via SLURP-1 is intriguing.

Concerning the studied transcription factors targeted by Chrna7, the stress did not regulate STAT3 but HIF1 $\alpha$. This provides additional information on the CS regulation of stress responses. HIF1 $\alpha$ was shown to be upregulated in MC when cells mature or locate near a bacterial infection (114116). Also, HIF1 $\alpha$ was upregulated simultaneously with MC infiltration in nasal epithelium of cigarette smoke exposed mice (117). This protects from infection, as MC exhibit increased microbicidal activity and more efficient control of invasive bacterial infection, when HIF1 $\alpha$ is increased (118). At the same time, oxidative stress and HIF $1 \alpha$ reduce $\mathrm{TNF} \alpha$ in MC through Chrna7 signaling $(78,81,119)$. Hence, through HIF1 $\alpha$ upregulation, the CS efficiently protects from bacterial infection by boosting innate immunity and hampering the switch to adaptive immunity. 
Moreover, HIF1 $\alpha$ upregulation together with stable or downregulated STAT3 may have implications for tumor growth as HIF $\alpha$ can hamper tumor growth. In a number of human and murine MC HIF1 $\alpha$ was shown to be upregulated when cells mature or locate near a tumor (114-116) and in meningeomas HIF $1 \alpha$ immunoreactivity correlates with occurrence of tryptase+ MC (120) suggesting a role for MC in the HIF1 $\alpha$ mediated defense against tumor growth. In addition, SLURP-1 was shown to abolish STAT3 upregulation in cancer cells (121).

Of course, our study has limitations. We used a purchasable recombinant SLURP-1 protein with a GST-tag at the N-terminal. As recently reported, N-terminal extensions could affect the activity and selectivity of SLURP-1 on its targets (100). Also, it cannot be excluded that SLURP-1 effects could be tissue-, cell- or dose-dependent and could depend on the nature of inflammatory stimuli and, respectively, the corresponding signaling pathways. As, immunohistochemically, SLURP-1 and Chrna7 expression was most prominent on sMC and nerve fibers, the present study focused on both as important players in the skin's CS stress response. Future studies should analyse the involvement of additional immune cells. Finally, the clinical relevance of our observations has to be tested in appropriate disease models, which is presently under way.

\section{CONCLUSION}

Taken together, our findings suggest that in stressed healthy skin, SLURP-1 induces a shift in the immune response toward a pro-inflammatory state and thereby enables the skin's CS to orchestrate an efficient defense against microbes and tumor cells, a response that aims at the maintenance of homeostasis (94). At the same time, this potentially puts the skin at risk for deleterious stress effects if hit by additional challenges. This could for example contribute to the stress-induced worsening of allergic inflammation that we had observed earlier (4). Evidently, the CS elements that were upregulated $24 \mathrm{~h}$ noise stress in healthy skin did not directly interact to activate MC and produce a pro-inflammatory cytokine profile. Instead, they teamed up to prepare the skin for an innate immune response (Figure 6) (122). Further investigations will show the relevance of these

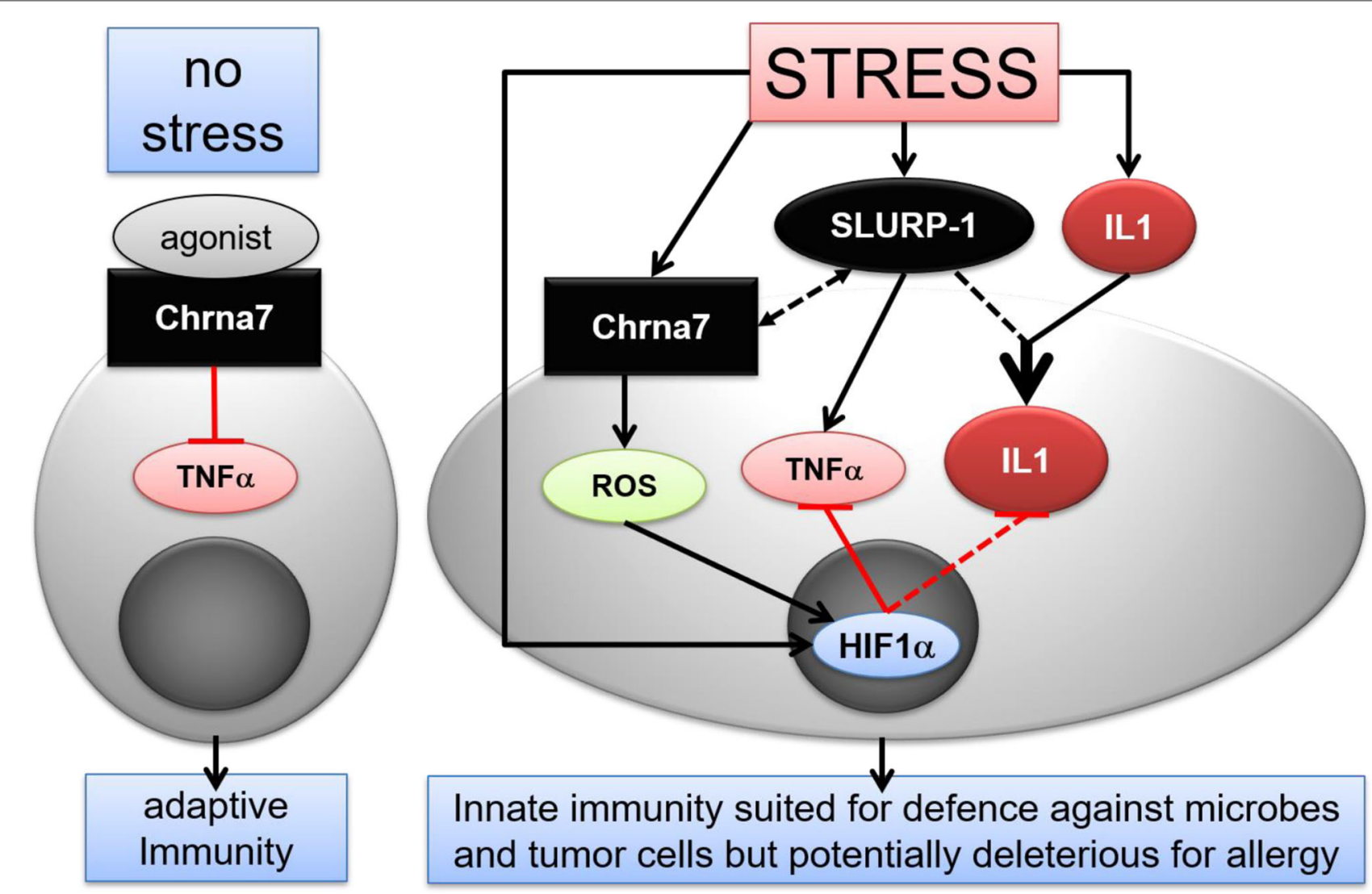

FIGURE 6 | Hypothetical scenario of stress interference with CS mediated immune modulatory effects in murine skin MC. Under normal conditions, activation of Chrna7 inhibits TNF $\alpha$ production by MC. In stress, however, SLURP-1 induces a shift in the immune response toward an innate pro-inflammatory state. SLURP-1 upregulates TNF $\alpha$ and IL1 $\beta$ expression by MC. Together with SLURP-1 and Chrna7, IL1 $\beta$, and HIF1 $\alpha$ are upregulated in MC by stress. Thereby, SLURP-1 promoted TNF $\alpha$ and IL1 $\beta$ production is inhibited by Chrna7 and ROS mediated HIF1 $\alpha$ upregulation. However, SLURP-1 and IL1 $\beta$ synergize to produce an innate pro-inflammatory state. Thereby SLURP-1 may act as an allosteric ligand to Chrna7 and through Chrna7-unrelated, yet to be identified receptors (45, 88). Chrna, alpha nicotinic acetylcholine receptor; HIF, hypoxia inducible factor; IL, interleukin; ROS, reactive oxygen species; SLURP, Secreted Ly-6/uPAR-related protein; TNF, tumor necrosis factor. 
results for the control of infectious diseases and cancer and for the treatment of non-infectious inflammatory disorders such as atopic dermatitis. This is presently tested in our laboratory in corresponding mouse models.

\section{DATA AVAILABILITY STATEMENT}

The original contributions presented in the study are included in the article/supplementary materials, further inquiries can be directed to the corresponding author/s.

\section{ETHICS STATEMENT}

The animal study was reviewed and approved by Landesamt für Arbeitsschutz, Gesundheitsschutz und technische Sicherheit, Berlin, Germany.

\section{AUTHOR CONTRIBUTIONS}

EP and UG designed the study. EP and CE drafted the manuscript. $\mathrm{CE}$ and FR conceived and carried out experiments. EP, YM, and JKl conceived experiments and analyzed data. ST carried out experiments. FR, YM, JKl, and JKr critically

\section{REFERENCES}

1. Chen Y, Lyga J. Brain-skin connection: stress, inflammation and skin aging. Inflamm Allergy Drug Targets. (2014) 13:177-90. doi: 10.2174/1871528113666140522104422

2. Peters EM, Arck PC, Paus R. Hair growth inhibition by psychoemotional stress: a mouse model for neural mechanisms in hair growth control. Experi Dermatol. (2006) 15:1-13. doi: 10.1111/j.0906-6705.2005.00372.x

3. Arck PC, Slominski A, Theoharides TC, Peters EM, Paus R. Neuroimmunology of stress: skin takes center stage. J Invest Dermatol. (2006) 126:1697-704. doi: 10.1038/sj.jid.5700104

4. Pavlovic S, Daniltchenko M, Tobin DJ, Hagen E, Hunt SP, Klapp BF, et al. Further exploring the brain-skin connection: stress worsens dermatitis via substance P-dependent neurogenic inflammation in mice. J Invest Dermatol. (2008) 128:434-46. doi: 10.1038/sj.jid.5701079

5. Kleyn CE, Schneider L, Saraceno R, Mantovani C, Richards HL, Fortune DG, et al. The effects of acute social stress on epidermal Langerhans' cell frequency and expression of cutaneous neuropeptides. I Invest Dermatol. (2008) 128:1273-9. doi: 10.1038/sj.jid.5701144

6. Peters EM, Liezmann C, Spatz K, Daniltchenko M, Joachim R, GimenezRivera A, et al. Nerve growth factor partially recovers inflamed skin from stress-induced worsening in allergic inflammation. J Invest Dermatol. (2011) 131:735-43. doi: 10.1038/jid.2010.317

7. Peters EM, Michenko A, Kupfer J, Kummer W, Wiegand S, Niemeier V, et al. Mental stress in atopic dermatitis-neuronal plasticity and the cholinergic system are affected in atopic dermatitis and in response to acute experimental mental stress in a randomized controlled pilot study. PLOS ONE. (2014) 9:e113552. doi: 10.1371/journal.pone.0113552

8. Hunter HJ, Momen SE, Kleyn CE. The impact of psychosocial stress on healthy skin. Clin Experi Dermatol. (2015) 40:540-6. doi: 10.1111/ced.12582

9. Dhabhar FS. Effects of stress on immune function: the good, the bad, the beautiful. Immunol Res. (2014) 58:193-210. doi: 10.1007/s12026-014-8517-0

10. Peters EMJ, Schedlowski M, Watzl C, Gimsa U. To stress or not to stress: Brain-behavior-immune interaction may weaken or promote the immune response to SARS-CoV-2. Neurobiol Stress. (2021) 14:100296. doi: 10.1016/j.ynstr.2021.100296 reviewed, edited, and commented the initial draft. All authors were involved in writing the paper and had final approval of the submitted and published versions.

\section{FUNDING}

This study was supported by the Landes-Offensive zur Entwickling Wissenschaftlich-ökonomischer Exzellenz (LOEWE) of the state Hesse Focus Group Non-neuronal cholinergic systems to EP and UG and research support by the Universitätsmedizin-Charité, Berlin, Germany to EP. The founding source was not involved in the study design; the collection, analysis and interpretation of data; writing of the report; or decision to submit the article for publication.

\section{ACKNOWLEDGMENTS}

We thank Maria Daniltchenko for her excellent technical advice and Liane Renno for her support with the Chrna7-KO mice. We also thank Jörg Scheffel for his guidance in establishing the $\beta$ hexosaminidase degranulation assay, Badrinarayanan Raghavan for his sound scientific technical support and Anna-Lena Urban for assistance in preparing the full thickness skin PCR data.

11. Slominski AT, Zmijewski MA, Skobowiat C, Zbytek B, Slominski RM, Steketee JD. Sensing the environment: regulation of local and global homeostasis by the skin's neuroendocrine system. Adv Anat Embryol Cell Biol. (2012) 212:1-115. doi: 10.1007/978-3-642-19683-6

12. Ofek K, Soreq H. Cholinergic involvement and manipulation approaches in multiple system disorders. Chem-Biol Interactions. (2013) 203:113-9. doi: 10.1016/j.cbi.2012.07.007

13. Reardon C. Neuro-immune interactions in the cholinergic anti-inflammatory reflex. Immunol Lett. (2016) 178:92-6. doi: 10.1016/j.imlet.2016.08.006

14. Fujii T, Mashimo M, Moriwaki Y, Misawa H, Ono S, Horiguchi K, et al. Expression and function of the cholinergic system in immune cells. Front Immunol. (2017) 8:1085. doi: 10.3389/fimmu.2017.01085

15. Gareau MG, Jury J, Perdue MH. Neonatal maternal separation of rat pups results in abnormal cholinergic regulation of epithelial permeability. Am J Physiol Gastrointest Liver Physiol. (2007) 293:G198-203. doi: 10.1152/ajpgi.00392.2006

16. Curtis BJ, Plichta JK, Blatt H, Droho S, Griffin TM, Radek KA. Nicotinic acetylcholine receptor stimulation impairs epidermal permeability barrier function and recovery and modulates cornified envelope proteins. Life Sci. (2012) 91:1070-6. doi: 10.1016/j.lfs.2012.08.020

17. Grando SA, Pittelkow MR, Schallreuter KU. Adrenergic and cholinergic control in the biology of epidermis: physiological and clinical significance. J Invest Dermatol. (2006) 126:1948-65. doi: 10.1038/sj.jid.5700151

18. Kurzen H, Wessler I, Kirkpatrick CJ, Kawashima K, Grando SA. The nonneuronal cholinergic system of human skin. Hormone Metab Res. (2007) 39:125-35. doi: 10.1055/s-2007-961816

19. Kindt F, Wiegand S, Niemeier V, Kupfer J, Loser C, Nilles M, et al. Reduced expression of nicotinic alpha subunits 3, 7, 9 and 10 in lesional and nonlesional atopic dermatitis skin but enhanced expression of alpha subunits 3 and 5 in mast cells. Brit J Dermatol. (2008) 159:847-57. doi: 10.1111/j.1365-2133.2008.08774.x

20. Kageyama-Yahara N, Suehiro Y, Yamamoto T, Kadowaki M. IgE-induced degranulation of mucosal mast cells is negatively regulated via nicotinic acetylcholine receptors. Biochem Biophys Res Commun. (2008) 377:321-5. doi: 10.1016/j.bbrc.2008.10.004 
21. Mishra NC, Rir-sima-ah J, Boyd RT, Singh SP, Gundavarapu S, Langley RJ, et al. Nicotine inhibits Fc epsilon RI-induced cysteinyl leukotrienes and cytokine production without affecting mast cell degranulation through alpha 7/alpha 9/alpha 10-nicotinic receptors. J Immunol. (2010) 185:588-96. doi: 10.4049/jimmunol.0902227

22. Uteshev VV. Allosteric modulation of nicotinic acetylcholine receptors: the concept and therapeutic trends. Curr Pharmaceut Design. (2016) 22:1986-97. doi: $10.2174 / 1381612822666160201115341$

23. Wessler I, Reinheimer T, Kilbinger H, Bittinger F, Kirkpatrick CJ, Saloga J, et al. Increased acetylcholine levels in skin biopsies of patients with atopic dermatitis. Life Sci. (2003) 72:2169-72. doi: 10.1016/S0024-3205(03)00079-1

24. Chernyavsky AI, Marchenko S, Phillips C, Grando SA. Auto/paracrine nicotinergic peptides participate in cutaneous stress response to wounding. Dermatoendocrinol. (2012) 4:324-30. doi: 10.4161/derm.22594

25. Antunes GL, Silveira JS, Kaiber DB, Luft C, da Costa MS, Marques EP, et al. Cholinergic anti-inflammatory pathway confers airway protection against oxidative damage and attenuates inflammation in an allergic asthma model. J Cell Physiol. (2019) 235:1838-49. doi: 10.1002/jcp.29101

26. Dhabhar FS, Saul AN, Daugherty C, Holmes TH, Bouley DM, Oberyszyn TM. Short-term stress enhances cellular immunity and increases early resistance to squamous cell carcinoma. Brain Behav Immun. (2010) 24:12737. doi: 10.1016/j.bbi.2009.09.004

27. Dhabhar FS. Psychological stress and immunoprotection versus immunopathology in the skin. Clin Dermatol. (2013) 31:18-30. doi: 10.1016/j.clindermatol.2011.11.003

28. Stalder JF, Tennstedt D, Deleuran M, Fabbrocini G, de Lucas R, Haftek M, et al. Fragility of epidermis and its consequence in dermatology. J Euro Acad Dermatol Venereol. (2014) 4:1-18. doi: 10.1111/jdv.12509

29. Pasparakis M, Haase I, Nestle FO. Mechanisms regulating skin immunity and inflammation. Nat Rev Immunol. (2014) 14:289-301. doi: 10.1038/nri3646

30. Watson IP, Brune M, Bradley AJ. The evolution of the molecular response to stress and its relevance to trauma and stressor-related disorders. Neurosci Biobehav Rev. (2016) 68:134-47. doi: 10.1016/j.neubiorev.2016. 05.010

31. Galli SJ, Nakae S, Tsai M. Mast cells in the development of adaptive immune responses. Nat Immunol. (2005) 6:135-42. doi: 10.1038/ni1158

32. Metz M, Grimbaldeston MA, Nakae S, Piliponsky AM, Tsai M, Galli SJ. Mast cells in the promotion and limitation of chronic inflammation. Immunol Rev. (2007) 217:304-28. doi: 10.1111/j.1600-065X.2007.00520.x

33. Peters EM, Liezmann C, Klapp BF, Kruse J. The neuroimmune connection interferes with tissue regeneration and chronic inflammatory disease in the skin. Ann N Y Acad Sci. (2012) 1262:118-26. doi: $10.1111 / j .1749-6632.2012 .06647 . x$

34. Undem BJ, Taylor-Clark T. Mechanisms underlying the neuronal-based symptoms of allergy. J Allergy Clin Immunol. (2014) 133:1521-34. doi: 10.1016/j.jaci.2013.11.027

35. Krystel-Whittemore M, Dileepan KN, Wood JG. Mast cell: a multi-functional master cell. Front Immunol. (2015) 6:620. doi: 10.3389/fimmu.2015.00620

36. Peters EM, Kuhlmei A, Tobin DJ, Muller-Rover S, Klapp BF, Arck PC. Stress exposure modulates peptidergic innervation and degranulates mast cells in murine skin. Brain Behav Immun. (2005) 19:252-62. doi: 10.1016/j.bbi.2004.08.005

37. Arndt J, Smith N, Tausk F. Stress and atopic dermatitis. Curr Allergy Asthma Rep. (2008) 8:312-7. doi: 10.1007/s11882-008-0050-6

38. Reich A, Wojcik-Maciejewicz A, Slominski AT. Stress and the skin. Giornale Italiano Dermatol Venereol. (2010) 145:213-9.

39. Dave ND, Xiang L, Rehm KE, Marshall GD. Stress and allergic diseases. Immunol Allergy Clin North Am. (2011) 31:55-68. doi: 10.1016/j.iac.2010.09.009

40. Rasul A, El-Nour H, Blakely RD, Lonne-Rahm SB, Forsberg J, Johansson B, et al. Effect of chronic mild stress on serotonergic markers in the skin and brain of the NC/Nga atopic-like mouse strain. Arch Dermatol Res. (2011) 303:625-33. doi: 10.1007/s00403-011-1138-8

41. Theoharides TC, Alysandratos KD, Angelidou A, Delivanis DA, Sismanopoulos N, Zhang B, et al. Mast cells and inflammation. Biochim Biophys Acta. (2012) 1822:21-33. doi: 10.1016/j.bbadis.2010. 12.014
42. Ohmura T, Tsunenari I, Hayashi T, Satoh Y, Konomi A, Nanri H, et al. Role of substance $\mathrm{P}$ in an $\mathrm{NC} / \mathrm{Nga}$ mouse model of atopic dermatitislike disease. Int Arch Allergy Immunol. (2004) 133:389-97. doi: 10.1159/ 000077359

43. Chernyavsky AI, Kalantari-Dehaghi M, Phillips C, Marchenko S, Grando SA. Novel cholinergic peptides SLURP-1 and -2 regulate epithelialization of cutaneous and oral wounds. Wound Repair Regen. (2012) 20:103-13. doi: 10.1111/j.1524-475X.2011.00753.x

44. Moriwaki Y, Watanabe Y, Shinagawa T, Kai M, Miyazawa M, Okuda T, et al. Primary sensory neuronal expression of SLURP-1, an endogenous nicotinic acetylcholine receptor ligand. Neurosci Res. (2009) 64:403-12. doi: 10.1016/j.neures.2009.04.014

45. Narumoto O, Niikura Y, Ishii S, Morihara H, Okashiro S, Nakahari $\mathrm{T}$, et al. Effect of secreted lymphocyte antigen-6/urokinase-type plasminogen activator receptor-related peptide-1 (SLURP-1) on airway epithelial cells. Biochem Biophys Res Commun. (2013) 438:175-9. doi: 10.1016/j.bbrc.2013.07.048

46. Upadhyay G. Emerging role of lymphocyte antigen-6 family of genes in cancer and immune cells. Front Immunol. (2019) 10:819. doi: 10.3389/fimmu.2019.00819

47. Peters EM, Hendrix S, Golz G, Klapp BF, Arck PC, Paus R. Nerve growth factor and its precursor differentially regulate hair cycle progression in mice. J Histochem Cytochem. (2006) 54:275-88. doi: 10.1369/jhc.4A6585.2005

48. Mrabet-Dahbi S, Metz M, Dudeck A, Zuberbier T, Maurer M. Murine mast cells secrete a unique profile of cytokines and prostaglandins in response to distinct TLR2 ligands. Experi Dermatol. (2009) 18:437-44. doi: $10.1111 / j .1600-0625.2009 .00878 . x$

49. Orr-Urtreger A, Goldner FM, Saeki M, Lorenzo I, Goldberg L, De Biasi $M$, et al. Mice deficient in the alpha7 neuronal nicotinic acetylcholine receptor lack alpha-bungarotoxin binding sites and hippocampal fast nicotinic currents. J Neurosci. (1997) 17:9165-71. doi: 10.1523/JNEUROSCI.17-23-09165.1997

50. Moser N, Mechawar N, Jones I, Gochberg-Sarver A, Orr-Urtreger A, Plomann $\mathrm{M}$, et al. Evaluating the suitability of nicotinic acetylcholine receptor antibodies for standard immunodetection procedures. J Neurochem. (2007) 102:479-92. doi: 10.1111/j.1471-4159.2007.04498.x

51. Rommel FR, Raghavan B, Paddenberg R, Kummer W, Tumala S, Lochnit G, et al. Suitability of nicotinic acetylcholine receptor alpha7 and muscarinic acetylcholine receptor 3 antibodies for immune detection: evaluation in murine skin. J Histochem Cytochem. (2015) 63:329-39. doi: $10.1369 / 0022155415575028$

52. Peters EM, Handjiski B, Kuhlmei A, Hagen E, Bielas H, Braun A, et al. Neurogenic inflammation in stress-induced termination of murine hair growth is promoted by nerve growth factor. Am J Pathol. (2004) 165:259-71. doi: 10.1016/S0002-9440(10)63294-4

53. Liberzon I, Abelson JL, Flagel SB, Raz J, Young EA. Neuroendocrine and psychophysiologic responses in PTSD: a symptom provocation study. Neuropsychopharmacol. (1999) 21:40-50. doi: 10.1016/S0893-133X(98)00128-6

54. Arck PC, Handjiski B, Hagen E, Joachim R, Klapp BF, Paus R. Indications for a 'brain-hair follicle axis (BHA)': inhibition of keratinocyte proliferation and up-regulation of keratinocyte apoptosis in telogen hair follicles by stress and substance P. FASEB J. (2001) 15:2536-8. doi: 10.1096/fj.00-0699fje

55. Peters EM, Botchkarev VA, Müller-Röver S, Moll I, Rice FL, Paus R Developmental timing of hair follicle and dorsal skin innervation in mice. J Compar Neurol. (2002) 448:28-52. doi: 10.1002/cne.10212

56. Hendrix S, Picker B, Liezmann C, Peters EM. Skin and hair follicle innervation in experimental models: a guide for the exact and reproducible evaluation of neuronal plasticity. Experi Dermatol. (2008) 17:214-27. doi: 10.1111/j.1600-0625.2007.00653.x

57. Hillert $\mathrm{MH}$, Imran I, Zimmermann $\mathrm{M}$, Lau $\mathrm{H}$, Weinfurter S, Klein J. Dynamics of hippocampal acetylcholine release during lithium-pilocarpineinduced status epilepticus in rats. J Neurochem. (2014) 131:42-52. doi: 10.1111/jnc.12787

58. Eissa N, Hussein H, Wang H, Rabbi MF, Bernstein CN, Ghia JE. Stability of reference genes for messenger RNA quantification by real-time PCR in mouse dextran sodium sulfate experimental colitis. PLoS ONE. (2016) 11:e0156289. doi: 10.1371/journal.pone.0156289 
59. Pfaffl MW. A new mathematical model for relative quantification in realtime RT-PCR. Nucleic Acids Res. (2001) 29:e45. doi: 10.1093/nar/29.9.e45

60. Convente MR, Chakkalakal SA, Yang E, Caron RJ, Zhang D, Kambayashi $\mathrm{T}$, et al. Depletion of mast cells and macrophages impairs heterotopic ossification in an Acvr1(R206H) mouse model of fibrodysplasia ossificans progressiva. J Bone Miner Res. (2018) 33:269-82. doi: 10.1002/jbmr.3304

61. Niu XL, Huang Y, Gao YL, Sun YZ, Han Y, Chen HD, et al. Interleukin18 exacerbates skin inflammation and affects microabscesses and scale formation in a mouse model of imiquimod-induced psoriasis. Chin Med J. (2019) 132:690-8. doi: 10.1097/CM9.0000000000000140

62. Bennett L, Kersaitis C, Macaulay SL, Munch G, Niedermayer G, Nigro J, et al. Vitamin D2-enriched button mushroom (Agaricus bisporus) improves memory in both wild type and APPswe/PS1dE9 transgenic mice. PLoS ONE. (2013) 8:e76362. doi: 10.1371/journal.pone.0076362

63. Bottoms SE, Howell JE, Reinhardt AK, Evans IC, McAnulty RJ. Tof-Beta isoform specific regulation of airway inflammation and remodelling in a murine model of asthma. PLoS ONE. (2010) 5:e9674. doi: 10.1371/journal.pone.0009674

64. Matthews DA, Salvaterra PM, Crawford GD, Houser CR, Vaughn JE. An immunocytochemical study of choline acetyltransferase-containing neurons and axon terminals in normal and partially deafferented hippocampal formation. Brain Res. (1987) 402:30-43. doi: 10.1016/0006-8993(87)91044-4

65. Nunes NS, Chandran P, Sundby M, Visioli F, da Costa Goncalves F, Burks SR, et al. Therapeutic ultrasound attenuates DSS-induced colitis through the cholinergic anti-inflammatory pathway. EBioMedicine. (2019) 45:495-510. doi: 10.1016/j.ebiom.2019.06.033

66. Zimmermann AS, Morrison SD, Hu MS, Li S, Nauta A, Sorkin M, et al. Epidermal or dermal specific knockout of PHD-2 enhances wound healing and minimizes ischemic injury. PLoS ONE. (2014) 9:e93373. doi: 10.1371/journal.pone.0093373

67. Brenner E, Schorg BF, Ahmetlic F, Wieder T, Hilke FJ, Simon N, et al. Cancer immune control needs senescence induction by interferon-dependent cell cycle regulator pathways in tumours. Nat Commun. (2020) 11:1335. doi: 10.1038/s41467-020-14987-6

68. Botchkarev VA, Eichmüller S, Peters EM, Pietsch P, Johansson O, Maurer M, et al. A simple immunofluorescence technique for simultaneous visualization of mast cells and nerve fibers reveals selectivity and hair cycle-dependent changes in mast cell-nerve fiber contacts in murine skin. Arch Dermatol Res. (1997) 289:292-302. doi: 10.1007/s004030050195

69. Meurer SK, Ness M, Weiskirchen S, Kim P, Tag CG, Kauffmann M, et al. Isolation of mature (peritoneum-derived) mast cells and immature (bone marrow-derived) mast cell precursors from mice. PLoS ONE. (2016) 11:e0158104. doi: 10.1371/journal.pone.0158104

70. Magerl M, Lammel V, Siebenhaar F, Zuberbier T, Metz M, Maurer M. Non-pathogenic commensal Escherichia coli bacteria can inhibit degranulation of mast cells. Experi Dermatol. (2008) 17:427-35. doi: 10.1111/j.1600-0625.2008.00704.x

71. van der Kleij HP, Ma D, Redegeld FA, Kraneveld AD, Nijkamp FP, Bienenstock J. Functional expression of neurokinin 1 receptors on mast cells induced by IL-4 and stem cell factor. J Immunol. (2003) 171:2074-9. doi: 10.4049/jimmunol.171.4.2074

72. Bruni A, Bigon E, Boarato E, Mietto L, Leon A, Toffano G. Interaction between nerve growth factor and lysophosphatidylserine on rat peritoneal mast cells. FEBS Lett. (1982) 138:190-2. doi: 10.1016/0014-5793(82)80438-9

73. Hua S, Ek CJ, Mallard C, Johansson ME. Perinatal hypoxia-ischemia reduces alpha 7 nicotinic receptor expression and selective alpha 7 nicotinic receptor stimulation suppresses inflammation and promotes microglial Mox phenotype. BioMed Res Int. (2014) 2014:718769. doi: 10.1155/2014/718769

74. Diaz BL, Fujishima H, Kanaoka Y, Urade Y, Arm JP. Regulation of prostaglandin endoperoxide synthase- 2 and IL- 6 expression in mouse bone marrow-derived mast cells by exogenous but not endogenous prostanoids. $J$ Immunol. (2002) 168:1397-404. doi: 10.4049/jimmunol.168.3.1397

75. Ko MJ, Lim CY. General considerations for sample size estimation in animal study. Korean J Anesthesiol. (2021) 74:23-29. doi: 10.4097/kja.20662

76. Peters EM, Botchkarev VA, Botchkareva NV, Tobin DJ, Paus R. Haircycle-associated remodeling of the peptidergic innervation of murine skin, and hair growth modulation by neuropeptides. J Invest Dermatol. (2001) 116:236-45. doi: 10.1046/j.1523-1747.2001.01232.x
77. Shi D, Guo W, Chen W, Fu L, Wang J, Tian Y, et al. Nicotine promotes proliferation of human nasopharyngeal carcinoma cells by regulating alpha7AChR, ERK, HIF-1alpha and VEGF/PEDF signaling. PLOS ONE. (2012) 7:e43898. doi: 10.1371/journal.pone.0043898

78. Guo L, Li L, Wang W, Pan Z, Zhou Q, Wu Z. Mitochondrial reactive oxygen species mediates nicotine-induced hypoxia-inducible factor-1alpha expression in human non-small cell lung cancer cells. Biochim Biophys Acta. (2012) 1822:852-61. doi: 10.1016/j.bbadis.2012.02.004

79. Zhang Q, Tang X, Zhang ZF, Velikina R, Shi S, Le AD. Nicotine induces hypoxia-inducible factor-1alpha expression in human lung cancer cells via nicotinic acetylcholine receptor-mediated signaling pathways. Clin Cancer Res. (2007) 13:4686-94. doi: 10.1158/1078-0432.CCR-06-2898

80. Filippini P, Cesario A, Fini M, Locatelli F, Rutella S. The Yin and Yang of nonneuronal alpha7-nicotinic receptors in inflammation and autoimmunity. Curr Drug Targets. (2012) 13:644-55. doi: 10.2174/138945012800399008

81. Dewhirst MW, Cao Y, Moeller B. Cycling hypoxia and free radicals regulate angiogenesis and radiotherapy response. Nat Rev Cancer. (2008) 8:425-37. doi: $10.1038 / \mathrm{nrc} 2397$

82. Lindqvist D, Dhabhar FS, James SJ, Hough CM, Jain FA, Bersani FS, et al. Oxidative stress, inflammation and treatment response in major depression. Psychoneuroendocrinology. (2017) 76:197-205. doi: 10.1016/j.psyneuen.2016.11.031

83. Fischer J, Bouadjar B, Heilig R, Huber M, Lefevre C, Jobard F, et al. Mutations in the gene encoding SLURP-1 in Mal de meleda. Human Mol Gene. (2001) 10:875-80. doi: $10.1093 / \mathrm{hmg} / 10.8 .875$

84. Perez C, Khachemoune A. Mal de Meleda: a focused review. Am J Clin Dermatol. (2016) 17:63-70. doi: 10.1007/s40257-015-0157-1

85. Adermann K, Wattler F, Wattler S, Heine G, Meyer M, Forssmann WG, et al. Structural and phylogenetic characterization of human SLURP-1, the first secreted mammalian member of the Ly-6/uPAR protein superfamily. Protein Sci. (1999) 8:810-9. doi: 10.1110/ps.8.4.810

86. Mastrangeli R, Donini S, Kelton CA, He C, Bressan A, Milazzo F, et al. ARS Component $\mathrm{B}$ : structural characterization, tissue expression and regulation of the gene and protein (SLURP-1) associated with Mal de Meleda. Eur J Dermatol. (2003) 13:560-70.

87. Yamamoto T, Kodama T, Lee J, Utsunomiya N, Hayashi S, Sakamoto H, et al. Anti-allergic role of cholinergic neuronal pathway via alpha7 nicotinic ACh receptors on mucosal mast cells in a murine food allergy model. PLoS ONE. (2014) 9:e85888. doi: 10.1371/journal.pone.0085888

88. Chernyavsky AI, Galitovskiy V, Shchepotin IB, Grando SA. Antiinflammatory effects of the nicotinergic peptides SLURP-1 and SLURP-2 on human intestinal epithelial cells and immunocytes. BioMed Res Int. (2014) 2014:609086. doi: 10.1155/2014/609086

89. Wang $\mathrm{H}, \mathrm{Yu} \mathrm{M}$, Ochani $\mathrm{M}$, Amella CA, Tanovic M, Susarla S, et al. Nicotinic acetylcholine receptor alpha7 subunit is an essential regulator of inflammation. Nature. (2003) 421:384-8. doi: 10.1038/nature01339

90. Faghih R, Gfesser GA, Gopalakrishnan M. Advances in the discovery of novel positive allosteric modulators of the alpha7 nicotinic acetylcholine receptor. Recent Pat CNS Drug Discov. (2007) 2:99-106. doi: 10.2174/157488907780832751

91. Tsoyi K, Jang HJ, Kim JW, Chang HK, Lee YS, Pae HO, et al. Stimulation of alpha7 nicotinic acetylcholine receptor by nicotine attenuates inflammatory response in macrophages and improves survival in experimental model of sepsis through heme oxygenase-1 induction. Antioxid Redox Signal. (2011) 14:2057-70. doi: 10.1089/ars.2010.3555

92. Sun L, Zhang GF, Zhang X, Liu Q, Liu JG, Su DF, et al. Combined administration of anisodamine and neostigmine produces anti-shock effects: involvement of alpha7 nicotinic acetylcholine receptors. Acta Pharmacol Sin. (2012) 33:761-6. doi: 10.1038/aps.2012.26

93. Pereira MR, Leite PE. The Involvement of Parasympathetic and Sympathetic Nerve in the Inflammatory Reflex. J Cell Physiol. (2016) 231:1862-9. doi: $10.1002 /$ jcp. 25307

94. Lyukmanova EN, Shulepko MA, Kudryavtsev D, Bychkov ML, Kulbatskii DS, Kasheverov IE, et al. Human secreted Ly-6/uPAR related protein-1 (SLURP-1) is a selective allosteric antagonist of alpha7 nicotinic acetylcholine receptor. PLoS ONE. (2016) 11:e0149733. doi: 10.1371/journal.pone.0149733

95. Throm VM, Mannle D, Giese T, Bauer AS, Gaida MM, Kopitz J, et al. Endogenous CHRNA7-ligand SLURP1 as a potential tumor suppressor and 
anti-nicotinic factor in pancreatic cancer. Oncotarget. (2018) 9:11734-51. doi: 10.18632 /oncotarget. 24312

96. Tjiu JW, Lin PJ, Wu WH, Cheng YP, Chiu HC, Thong HY, et al. SLURP1 mutation-impaired T-cell activation in a family with mal de Meleda. Brit $J$ Dermatol. (2011) 164:47-53. doi: 10.1111/j.1365-2133.2010.10059.x

97. Vegas O, Poligone B, Blackcloud P, Gilmore ES, VanBuskirk J, Ritchlin CT, et al. Chronic social stress Ameliorates psoriasiform dermatitis through upregulation of the Hypothalamic-Pituitary-Adrenal axis. Brain Behav Immun. (2018) 68:238-47. doi: 10.1016/j.bbi.2017.10.022

98. Marsland AL, Walsh C, Lockwood K, John-Henderson NA. The effects of acute psychological stress on circulating and stimulated inflammatory markers: a systematic review and meta-analysis. Brain Behav Immun. (2017) 64:208-19. doi: 10.1016/j.bbi.2017.01.011

99. Theoharides TC, Kempuraj D, Tagen M, Conti P, Kalogeromitros D. Differential release of mast cell mediators and the pathogenesis of inflammation. Immunol Rev. (2007) 217:65-78. doi: 10.1111/j.1600-065X.2007.00519.x

100. Durek T, Shelukhina IV, Tae HS, Thongyoo P, Spirova EN, Kudryavtsev DS, et al. Interaction of synthetic human SLURP-1 with the nicotinic acetylcholine receptors. Sci Rep. (2017) 7:16606. doi: 10.1038/s41598-017-16809-0

101. Koval L, Lykhmus O, Zhmak M, Khruschov A, Tsetlin V, Magrini E, et al. Differential involvement of alpha4beta2, alpha7 and alpha9alpha10 nicotinic acetylcholine receptors in B lymphocyte activation in vitro. Int $J$ Biochem Cell Biol. (2011) 43:516-24. doi: 10.1016/j.biocel.2010.12.003

102. Lykhmus O, Voytenko LP, Lips KS, Bergen I, Krasteva-Christ G, Vetter $\mathrm{DE}$, et al. Nicotinic acetylcholine receptor alpha9 and alpha10 subunits are expressed in the brain of mice. Front Cell Neurosci. (2017) 11:282. doi: 10.3389/fncel.2017.00282

103. Mucchietto V, Fasoli F, Pucci S, Moretti M, Benfante R, Maroli A, et al. alpha9- and alpha7-containing receptors mediate the pro-proliferative effects of nicotine in the A549 adenocarcinoma cell line. Brit J Pharmacol. (2018) 175:1957-72. doi: 10.1111/bph.13954

104. Backhaus S, Zakrzewicz A, Richter K, Damm J, Wilker S, Fuchs-Moll G, et al. Surfactant inhibits ATP-induced release of interleukin-1beta via nicotinic acetylcholine receptors. J Lipid Res. (2017) 58:1055-66. doi: 10.1194/jlr.M071506

105. Bonnekoh H, Scheffel J, Kambe N, Krause K. The role of mast cells in autoinflammation. Immunol Rev. (2018) 282:265-75. doi: 10.1111/imr.12633

106. Jiang $\mathrm{T}$, Wu M, Zhang Z, Yan C, Ma Z, He S, et al. Electroacupuncture attenuated cerebral ischemic injury and neuroinflammation through alpha7nAChR-mediated inhibition of NLRP3 inflammasome in stroke rats. Mol Med. (2019) 25:22. doi: 10.1186/s10020-019-0091-4

107. Tang L, Zhou F. Inflammasomes in common immune-related skin diseases. Front Immunol. (2020) 11:882. doi: 10.3389/fimmu.2020.00882

108. Tsuji G, Hashimoto-Hachiya A, Yen VH, Takemura M, Yumine A, Furue K, et al. Metformin inhibits IL-1beta secretion via impairment of NLRP3 inflammasome in keratinocytes: implications for preventing the development of psoriasis. Cell Death Discov. (2020) 6:11. doi: $10.1038 / \mathrm{s} 41420-020-0245-8$

109. Meng G, Zhang F, Fuss I, Kitani A, Strober W. A mutation in the Nlrp3 gene causing inflammasome hyperactivation potentiates Th17 cell-dominant immune responses. Immunity. (2009) 30:860-74. doi: 10.1016/j.immuni.2009.04.012

110. Besnard AG, Guillou N, Tschopp J, Erard F, Couillin I, Iwakura $\mathrm{Y}$, et al. NLRP3 inflammasome is required in murine asthma in the absence of aluminum adjuvant. Allergy. (2011) 66:1047-57. doi: 10.1111/j.1398-9995.2011.02586.x

111. Finnell JE, Wood SK. Putative inflammatory sensitive mechanisms underlying risk or resilience to social stress. Front Behav Neurosci. (2018) 12:240. doi: 10.3389/fnbeh.2018.00240

112. da Rocha AL, Pinto AP, Kohama EB, Pauli JR, de Moura LP, Cintra DE, et al. The proinflammatory effects of chronic excessive exercise. Cytokine. (2019) 119:57-61. doi: 10.1016/j.cyto.2019.02.016

113. Hori H, Kim Y. Inflammation and post-traumatic stress disorder. Psychiatr Clin Neurosci. (2019) 73:143-53. doi: 10.1111/pcn.12820

114. Walczak-Drzewiecka A, Salkowska A, Ratajewski M, Dastych J. Epigenetic regulation of $\mathrm{CD} 34$ and HIF1A expression during the differentiation of human mast cells. Immunogenetics. (2013) 65:429-38. doi: 10.1007/s00251-013-0695-8

115. Liang X, Yin G, Ma Y, Xu K, Liu J, Li J. The critical role of mast cell-derived hypoxia-inducible factor-1alpha in regulating mast cell function. J Pharm Pharmacol. (2016) 68:1409-16. doi: 10.1111/jphp.12622

116. Jeong HJ, Oh HA, Nam SY, Han NR, Kim YS, Kim JH, et al. The critical role of mast cell-derived hypoxia-inducible factor-1alpha in human and mice melanoma growth. Int J Cancer. (2013) 132:2492-501. doi: 10.1002/ijc. 27937

117. Lee KI, Kim DW, Kim EH, Kim JH, Samivel R, Kwon JE, et al. Cigarette smoke promotes eosinophilic inflammation, airway remodeling, and nasal polyps in a murine polyp model. Am J Rhinol Allergy. (2014) 28:208-14. doi: 10.2500/ajra.2014.28.4055

118. Branitzki-Heinemann K, Okumura CY, Vollger L, Kawakami Y, Kawakami T, Naim HY, et al. A novel role for the transcription factor HIF-1alpha in the formation of mast cell extracellular traps. Biochem J. (2012) 446:159-63. doi: 10.1042/BJ20120658

119. Gulliksson M, Carvalho RF, Ulleras E, Nilsson G. Mast cell survival and mediator secretion in response to hypoxia. PLoS ONE. (2010) 5:e12360. doi: 10.1371/journal.pone.0012360

120. Reszec J, Hermanowicz A, Rutkowski R, Bernaczyk P, Mariak Z, Chyczewski L. Evaluation of mast cells and hypoxia inducible factor-1 expression in meningiomas of various grades in correlation with peritumoral brain edema. J Neurooncol. (2013) 115:119-25. doi: 10.1007/s11060-0131208-1

121. Kalantari-Dehaghi M, Bernard HU, Grando SA. Reciprocal effects of NNK and SLURP-1 on oncogene expression in target epithelial cells. Life Sci. (2012) 91:1122-5. doi: 10.1016/j.lfs.2012.02.004

122. Dhabhar FS. The short-term stress response - Mother nature's mechanism for enhancing protection and performance under conditions of threat, challenge, and opportunity. Front Neuroendocrinol. (2018) 49:175-92. doi: 10.1016/j.yfrne.2018.03.004

Conflict of Interest: The authors declare that the research was conducted in the absence of any commercial or financial relationships that could be construed as a potential conflict of interest.

Copyright (C) 2021 Ertle, Rommel, Tumala, Moriwaki, Klein, Kruse, Gieler and Peters. This is an open-access article distributed under the terms of the Creative Commons Attribution License (CC BY). The use, distribution or reproduction in other forums is permitted, provided the original author(s) and the copyright owner(s) are credited and that the original publication in this journal is cited, in accordance with accepted academic practice. No use, distribution or reproduction is permitted which does not comply with these terms. 